University of Missouri-Kansas City School of Law

UMKC School of Law Institutional Repository

\title{
Technology Changes Drive Legal Changes for Antibody Patents: What Patent Examiners Can Teach Courts About the Written Description and Enablement Requirements.
}

\author{
S. Sean Tu \\ Christopher M. Holman \\ University of Missouri - Kansas City, School of Law
}

Follow this and additional works at: https://irlaw.umkc.edu/faculty_works

Part of the Law Commons

\section{Recommended Citation}

S. Sean Tu \& Christopher M. Holman, Technology Changes Drive Legal Changes for Antibody Patents: What Patent Examiners Can Teach Courts About the Written Description and Enablement Requirements., (2022).

Available at: https://irlaw.umkc.edu/faculty_works/218

This Forthcoming Work is brought to you for free and open access by the Faculty Scholarship at UMKC School of Law Institutional Repository. It has been accepted for inclusion in Faculty Works by an authorized administrator of UMKC School of Law Institutional Repository. For more information, please contact shatfield@umkc.edu. 


\title{
Technology Changes Drive Legal Changes for Antibody Patents: What Patent Examiners Can Teach Courts About the Written Description and Enablement Requirements ${ }^{1}$
}

\author{
S. Sean $T u^{2}$ \\ Christopher M. Holman ${ }^{3}$
}

\begin{abstract}
Antibody patents form the basis of some of the most valuable biotechnology products on the market. In 2020 alone, the sales of the top three drugs exceed 10 billion dollars. Two of those three drugs are monoclonal antibodies (Humira and Keytruda). In the past, patent law offered broad protection for monoclonal antibodies. As time has progressed, however, courts have narrowed the scope of antibody patents. However, very little research has been done to see how patent examiners are applying the rules of patentability to these valuable antibody patents.
\end{abstract}

We examine approximately two decades worth of antibody patents to determine how the US Patent Office has dealt with antibody patents. Specifically, we examine every patent directed to an antibody composition of matter from 2001-present. We find that patent examiners have steadily increased the use of 112(a) enablement and written description rejections while slightly decreasing the use of anticipation and obviousness rejections. Accordingly, these data suggest that 112(a) plays a greater role in policing claim scope than prior art rejections, which is the most frequently used rejection type for every other technology center. Correspondingly, patent

1 (C) 2021 S. Sean Tu and Christopher M. Holman.

2 Professor, West Virginia University College of Law. Scholar, O'Neill Institute for National and Global Health Law, Georgetown Law. The authors would like to thank John Allison, Jonathan Darrow, Paul Gugliuzza, Yaniv Heled, Dmitry Karshtedt, Aaron Kesselheim, Mark Lemley, Michael Madison, Emily Michiko Morris, Lisa Ouellette, Rachel Sachs, Bhaven Sampat, Ameet Sarpatwari, David Schwartz, Jacob Sherkow, Saurabh Vishnubhakat, and the participants of the University of New Hampshire's 10th Annual IP Scholars' Roundtable and the Three Rivers IP and Technology Law Colloquium for their generous comments. This work was funded in part by the generous support of the West Virginia University College of Law Hodges Research Fund.

3 Professor, University of Missouri-Kansas City School of Law. 
2-Feb-22] Orange Book Patent Prosecution and Litigation

applicants have also changed the type of claims they are drafting. Claims have moved from broad claims based only on function to narrow claims based on antibody structure.

We also find that the number of antibody composition patents has dramatically increased, while the number of claims per patent has decreased. Additionally, the number of words in each independent claim has increased three-fold. These data present an interesting evolution for antibody patents that mirrors the changing nature of antibody technology and offers some insights for improving antibody patent prosecution.

\section{Table of Contents}

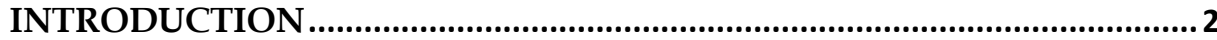

I. THE DATASETS.................................................................................. 4

A. THE ANTIBODY DATASET ......................................................................... 4

B. THE 1650 CONTROL GROUP DATASET .......................................................... 5

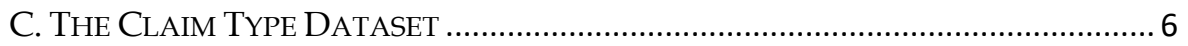

D. DATA LIMITATIONS .................................................................................. 7

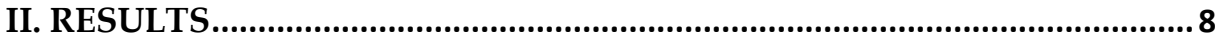

A. CHANGES IN ANTIBODY ClAIMS ..................................................................... 8

1. Increased Number of Written Description / Enablement Rejections ........8

2. Change in Type of Claims .................................................................. 9

3. Increase in the Number of Words Per Independent Claim..................... 10

B. ANTIBODY PATENT REJECTIONS .................................................................. 12

1. Antibody Claims in Comparison to Other Technologies........................ 12

2. Other Substantive Rejections and Antibody Patents............................. 13

C. Changes With Antibody Patent Prosecution Practice ........................ 15

1. Increasing Number of Antibody Patents............................................ 16

2. Fewer Claims Over Time …............................................................... 17

3. Fewer Original Patent Filings Over Time Compared to the 1650 Control 18

4. Shorter Patent Prosecution Duration Over Time................................. 20

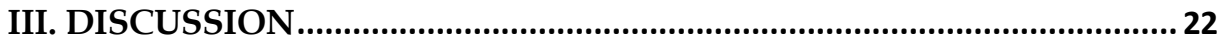

A. CHANGE IN Claim TyPE ............................................................................. 22

1. Early Antibody Claims: Antibody Claims Defined by Antigen Structure

Only 23

2. Replacing Broad Genus Claims: Antibody Claims Defined by Antibody

Complementarity Determining Regions (CDRs).................................................. 24

3. Narrow Species Claims: Antibody Claims Defined by Complete Antibody Structure 26 


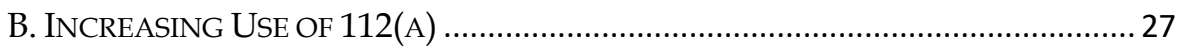

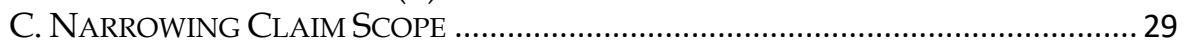

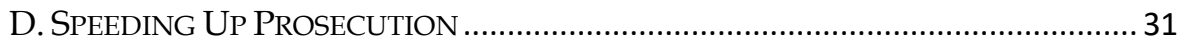

IV. IMPROVING ANTIBODY PATENT PROSECUTION ........................... 32

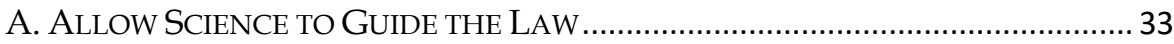

B. REVERSE DOCTRINE OF EQUIVALENTS …………............................................ 34

\section{INTRODUCTION}

Antibody patents are associated with some of the most valuable drugs in the world. In 2020, two of the top three selling drugs were monoclonal antibodies (Humira and Keytruda), bringing in billions of dollars in sales. In 2016 alone, Humira generated \$25.6 billion for AbbVie. As biologics overtake small molecules as the world's most valuable drugs, antibody patents play an increasingly important role to drug companies, medical insurance companies as well as consumers.

The evolution of antibody patents, however, has been one that has dramatically shifted from the early 2000s to present. Previously, antibody patents were granted broad genus type protection. Currently, however, antibody patents usually cover narrow specific antibodies that have well defined structures, especially when it comes to the structural elements that define the specific binding regions of the antibody.

This shift in scope has been proven by courts who have recently been apt to invalidate claims with broad scope. For example, the Federal Circuit just recently overturned a $\$ 1.1$ billion jury verdict on a biotechnology patent based on antibody type technology, finding the asserted claims too broad and thus invalid under the written description requirement. ${ }^{4}$

Changes in technology always move faster than changes to the law. Courts are constantly playing a game of catch up to new technological developments. In the patent realm there is an added layer of review by the USPTO. Changes to USPTO policy occur even slower than courts because the USPTO must respond to court

\footnotetext{
${ }^{4}$ Juno therapeutics, Inc. v. Kite Pharma, Inc. (Fed. Cir. August 26, 2021)
} 
decisions, usually in the form of guidance documents and/or examiner training materials. Accordingly, changes to patent policy at the prosecution level should, in theory, lag slowly behind changes in the law.

Surprisingly, our data show that patent examiners at the USPTO have been independently applying a higher standard of review for antibody patents even before the USPTO put out specific guidance and much earlier than current Federal Circuit caselaw. Specifically, patent examiners were increasingly using the enablement and written description requirements for biotechnology patents long before courts have been applying an enhanced 35 USC 112(a) requirement.

For most areas of technology, prior art rejections are the most difficult hurdle that applicants must overcome to obtain a patent. However, antibody patents face a very different challenge. Specifically, lack of enablement and not meeting the written description requirement seem to be the most difficult hurdles to overcome for antibody composition of matter claims. These types of challenges that are rare in most other technology areas are common for antibody technologies.

We argue that the enhanced 112(a) standard applied by examiners are keyed to changes in antibody technology and less keyed towards changes in the law. As antibody technology changed from being primarily used as a diagnostic tool to a therapeutic drug, patent examiners quickly adjusted to the technology by rejecting those broad antibody claims for lack of enablement and/or the necessary written description requirements.

Most USPTO examiners do not have a legal background, but all examiners are required to have a technical background. These data support the idea that patent examiners are able to respond to changes in technology well ahead of any formal guidance from the PTO and the courts. By applying a stricter standard for written description and enablement in response to changes in the technology, patent examiners have narrowed antibody claims to give exclusive rights to only those narrow claims that are supported by the disclosure of the specification. In this way, although the claims 
are narrower, they also avoid invalidation via anticipation and obviousness arguments.

In Part I, we discuss the databases that were created for this study. In Part II we present our results. In Part III we present how these results fit within 35 USC 112(a) jurisprudence. Finally, in Part IV we offer policy recommendations and a critique the current state of antibody patents based on our findings.

\section{THE DATASETS}

We created three unique datasets for this study. ${ }^{5}$ The goal of this study was to determine of antibody claims experience a different prosecution history compared to other biotechnology patents.

\section{A. The Antibody Dataset}

The first dataset comprises of over 6,000 patents containing antibody composition of matter patents (hereinafter antibody dataset). These patents had filing dates ranging from November 29, 2000 to June 1, 2021 and issue dates from June 18, 2002 to August 3, 2021.

Our initial search included every patent with the term "antibody" within the claim (over 46,000 patents). However, after reviewing the claims of numerous patents we determined that the dataset was too broad for our purposes and included many patents that were only tangentially related to antibodies. Accordingly, we used a title search using the term "antibod\$" which resulted in

5 S. Sean Tu's pertinent credentials are: B.S. in Microbiology and B.S. in Chemistry, University of Florida; Ph.D. in Pharmacology, Cornell University; Post-Doctoral Fellow, La Jolla Institute for Allergy and Immunology; Associate with Foley \& Lardner (Chemical, Biotechnology \& Pharmaceutical Practice/Life Science and Nanotechnology Industry Team).

Christopher Holman's pertinent credentials are: B.A. in Chemistry, California State University, Hayward; Ph.D. in Biochemistry and Molecular Biology, University of California, Davis; Post-Doctoral Fellow, Syntex Research/Roche Bioscience; Patent Agent with Flehr Hohbach, LLP.; Associate with Pennie \& Edmonds, LLP.; Associate Patent Counsel with Transgenomic, Inc.; Patent Counsel with Maxygen, Inc.; Vice-President, Intellectual Property with PhyNexus, Inc. 
15,285 patents. We then reviewed the titles of these patents to determine if the patents truly represented antibody composition of matter type subject matter. After reviewing these 15,285 and after liberally removing those patents not related to antibody composition of matter claims, we were left with 6,407 patents. To ensure consistent coding a sample of 400 patents were taken and reviewed by both authors. This review resulted in over $90 \%$ consistency.

These data represent mainly antibody composition of matter claims. Specifically, we attempted to eliminate those patents with only claims directed to drug conjugates, pharmaceutical compositions, methods of use, treatment claims, antibody libraries, polyclonal antibodies, transgenic mice used to produce antibodies, kits with antibodies and expression vectors. We retained patents directed towards: antibodies of any isotype (IgE, $\operatorname{IgA}, \operatorname{IgD}$, etc.), humanized and chimeric antibodies, bispecific antibodies, antibody fragments, nucleic acids encoding specific antibodies, neutralizing antibodies, engineered antibodies, and recombinant antibodies.

All the data has been grouped by the first office action date. This metric is better than the filing date because prosecution dates can change dependent on the examiner's docket and the backlog of patents at the patent office. Accordingly, filing dates can be deceptive because examiners may not pick up the application for long periods of time after the PTO receives the application. For example, US Patent No. 6,770,466 has a filing date of July 18, 2001. However, the first office action did not occur until June 12, 2003, about two years after the filing date. Therefore, using the first action date better represents the state of the law at the time the application was under review by the PTO.

\section{B. The 1650 Control Group Dataset}

A second data set was generated to act as a control group (hereinafter 1650 control group). This dataset consisted of over 92,000 patents from Workgroup 1650. ${ }^{6}$ The 1650 control group includes

${ }^{6}$ As shown in Section $\mathrm{II}(\mathrm{C})$ below, most antibody patents come from Workgroup 1640. Workgroup 1650 was chosen as a control group because this workgroup encompasses patents directed to "Fermentation, Microbiology, Isolated and Recombinant Proteins/Enzymes." Workgroup 
patents directed towards "isolated and recombinant proteins/enzymes."

Workgroup 1650 was chosen as a control because many of the characteristics of the patents found in workgroup 1640 (the workgroup associated with most antibody patents) could also be found in 1650. For example, many of the traits found in recombinant proteins and recombinant enzymes will be similar for antibody claims. For example, recombinant enzymes exhibit functional attributes that are tied to specific structural elements. Similarly, therapeutic antibodies exhibit functional characteristics based on the specific antibody Complementarity Determining Regions (CDRs). ${ }^{7}$ Additionally, only nine of the 6,408 antibody patents were found in workgroup 1650, so the overlap between these two datasets is minimal.

Similar to the antibody dataset, the 1650 control group was organized chronologically by the first action date.

\section{The Claim Type Dataset}

A third data set was generated to examine claim type (hereinafter claim type dataset). We sampled 340 independent patent claims from the antibody dataset. We reviewed 20 independent claims (Claim 1) from each year from 2002-2018. We determined if the antibody claim type was directed to an antibody as described: (1) by binding to a specific antigen (and giving the antigen description / epitope) or (2) structurally by its binding site or specific heavy chain / light chain sequences. Structural limitations were most frequently described as specific sequence identification numbers (SEQ ID). These SEQ ID numbers corresponded to either specific amino acid sequences or specific nucleotide sequences, usually corresponding to specific CDR regions.

Antibody claims can be very broad (based only on the description of the antigen) to fairly narrow (based on specific

1650 contains many of the same types of issues present in Workgroup 1640, which is directed to "Immunology, Receptor/Ligands, Cytokines Recombinant Hormones, and Molecular Biology."

${ }^{7}$ For a deeper discussion of CDRs, see Appendix 1. 
binding regions of the antibody along with a description of the antibody's function). In general, antibodies can be defined by: (1) reference to the target antigen; (2) the epitope; (3) target antigen and further antibody functional features; (4) antibody and structural features; (5) their own structure (amino acid sequences); (6) antibody nucleic acid sequences encoding the antibody; (7) the antibody production process; and/or the hybridoma producing antibody. In general, this list is ordered from broadest to narrowest type of antibody claims.

The broadest patents usually claim antibodies by only referencing the target antigen, without reciting any structural elements for the antibody. ${ }^{8}$ In contrast, the narrowest claims reference only the hybridoma that is used to produce the specific antibody, thus giving the complete antibody structure and the means to produce the antibody. ${ }^{9}$ In the claim type dataset, we consolidate antibody definitions 1-3 together (antibody defined by antigen structure and no antibody structure) and 4-7 together (antibody defined by its own structure).

\section{Data Limitations}

Because we are working with issued patents, there is a selection issue for recently granted patents with first office action dates of 2019, 2020 or 2021. Specifically, recently filed patents will always have much shorter prosecution histories simply because they have been reviewed by the PTO and issued very recently. Thus, many of these patents have prosecution histories that are not representative of most patents. Specifically, these patents usually come from large patent families which exhibit anomalous prosecution histories. To minimize this selection effect we have excluded all patents with first actions that occurred after 2019.

\footnotetext{
${ }^{8}$ An example of this broad claim would be, "An antibody that specifically binds $X^{\prime \prime}$. See, for example, US Patent No. 7060800.

${ }^{9}$ An example of this narrow claim would be, "A hybridoma cell line deposited as ATCC Accession Number X." See for example, US Patent No. 7,547,544. The hybridoma cell line claims are usually the least valuable to firms because they are easy to design around. Specifically, if a competitor develops an independent hybridoma cell line, even if the competitor's hybridoma cell line produces a very similar $\mathrm{mAb}$ to the patented hybridoma cell line, it will not infringe the patented cell line.
} 


\section{RESULTS}

First, we find that antibody patents experience many more 112(a) rejections compared to similar technology. Second, we find that antibody claims have shifted from broad functional claims defined by the antigen to narrower claims defined by the antibody structure. Third, there was a five-fold increase in the number antibody patents granted with a significant decrease in the number of independent claims per patent. Finally, the number of words per independent claim has also increased from 2002-2018, which also suggests a narrowing of antibody claims over time.

\section{A. Changes in Antibody Claims}

Antibody claims and the rejections that patent examiners apply to allow those claims has shifted dramatically from 2002-2018. Three areas of greatest changes are: (1) increased use of 112(a) rejections, (2) forcing applicants to narrow their claims by requiring structural elements that define the antibody, thus changing the type of antibody claim from claims that are defined only by the antigen's structure to claims that are defined by the antibody's structure, and (3) increased number of words necessary to claim the invention.

\section{Increased Number of Written Description / Enablement Rejections}

Patent examiners for antibody technology have dramatically increased their use of the written description and enablement rejection. Figure $1 \mathrm{~A}^{10}$ shows that from 2003-2006 antibody patents initially received 112 (a) rejections only about $20 \%$ of the time and almost doubles to $40 \%$ by $2018 .{ }^{11}$

A $20 \%$ rejection rate based on 112(a) is typical of biotechnology patents. As shown in Figure 1B, the 1650 control group does not

\footnotetext{
${ }^{10}$ These data have been segmented to show the percentage of office actions with specific types of rejections for: (1) first office actions, (2) non-final office actions, and (3) final office actions.

1135 U.S.C. 112(a) rejections include both written description and enablement rejections. These two rejections have been cojoined because examiners often confuse / conflate these two doctrines even though they are separate and distinct requirements. See Ariad Pharmaceuticals, Inc. v. Eli Lilly \& Co., 598 F.3d 1336 (Fed. Cir. 2010).
} 
show a discernable increase in 112(a) rejections over the same time period. Accordingly, examiners in the 1650 control group only use 112(a) rejections in the 1650 control group about $20 \%$ throughout 2002-present.

Figure 1A

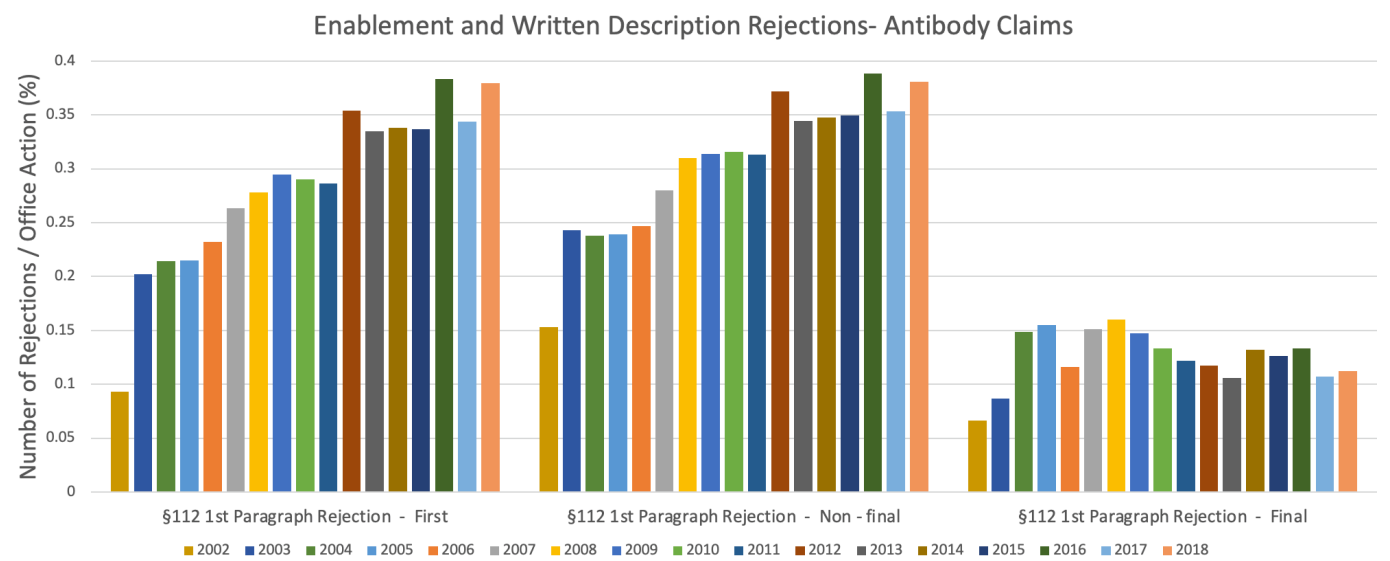

Figure 1B

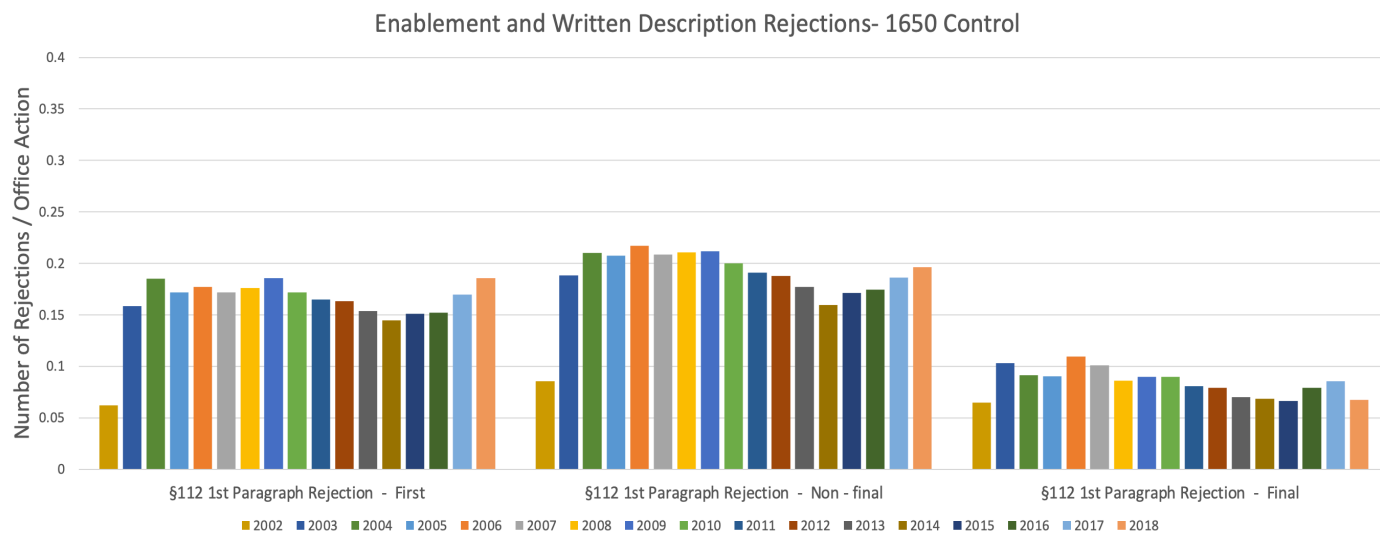

2. Change in Type of Claims

The way antibody claims are drafted has also dramatically changed from 2003 to $2019 .{ }^{12}$ As shown in Figure 2, in the early 2000 's approximately $70 \%$ of the claims were directed to antibodies Section I(B).

12 These data were based on the 340 patents from the Claim Type Dataset described in 
that were defined only by their antigen or antigen binding site, while about only $30 \%$ were defined by structural elements (usually given by the exact amino acid sequence of the six CDRs or the full light chain/heavy chain sequence). By 2011 we saw almost a complete switch. In 2011, almost no antibody claims were characterized only by their antigen binding site, and by the late 2010 's, almost $100 \%$ of the claims were completely defined by their structural elements.

Figure 2

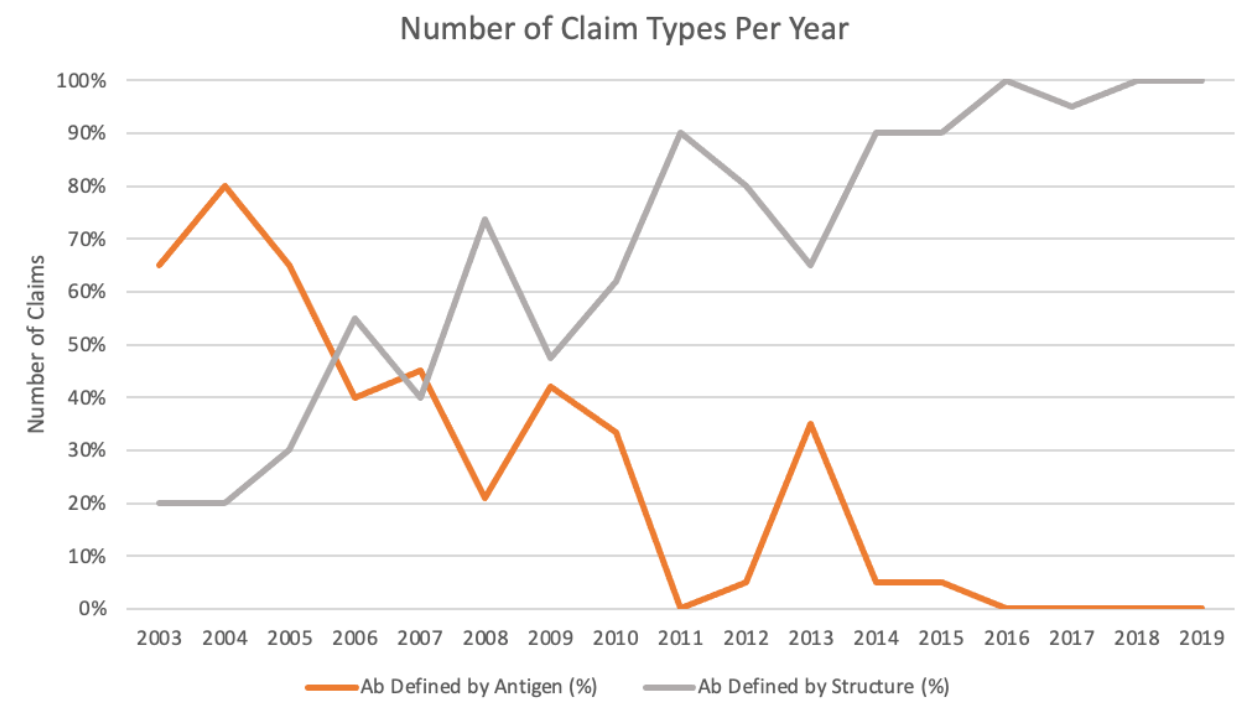

This change in the types of antibody claims allowed by examiners corresponds to the increase in the number of words in each claim ${ }^{13}$ as well as the increased use of 112(a) rejections. ${ }^{14}$ Currently patent examiners do not allow broad antibody claims described only by the antigen. Thus, antibody patents are much narrower because applicants must describe specific structures that correspond to the antibody they are attempting to claim and can no longer claim antibodies based solely on their antigen structure.

\section{Increase in the Number of Words Per Independent Claim}

In response to the increase in 112(a) rejections, applicants have been adding words to their claims. As shown in Figure 3A, the

\footnotetext{
${ }^{13}$ See Section II(A)(3) below.

${ }^{14}$ See Section II(A)(1) supra.
} 
2-Feb-22] Orange Book Patent Prosecution and Litigation

number of words in each independent claim has almost tripled from 2002 to $2018 .{ }^{15}$ Specifically, the number of words in each independent claim increased from approximately 60 words per independent claim in 2002 to over 160 words per claim in 2018. In comparison, as shown in Figure 3B, the number of words in each independent claim for the 1650 control group did not change that much, only growing from approximately 100 words per claim in 2002 to about 120 words per claim in 2018.

Figure 3A

Average Words per Independent Claims- Antibody Claims

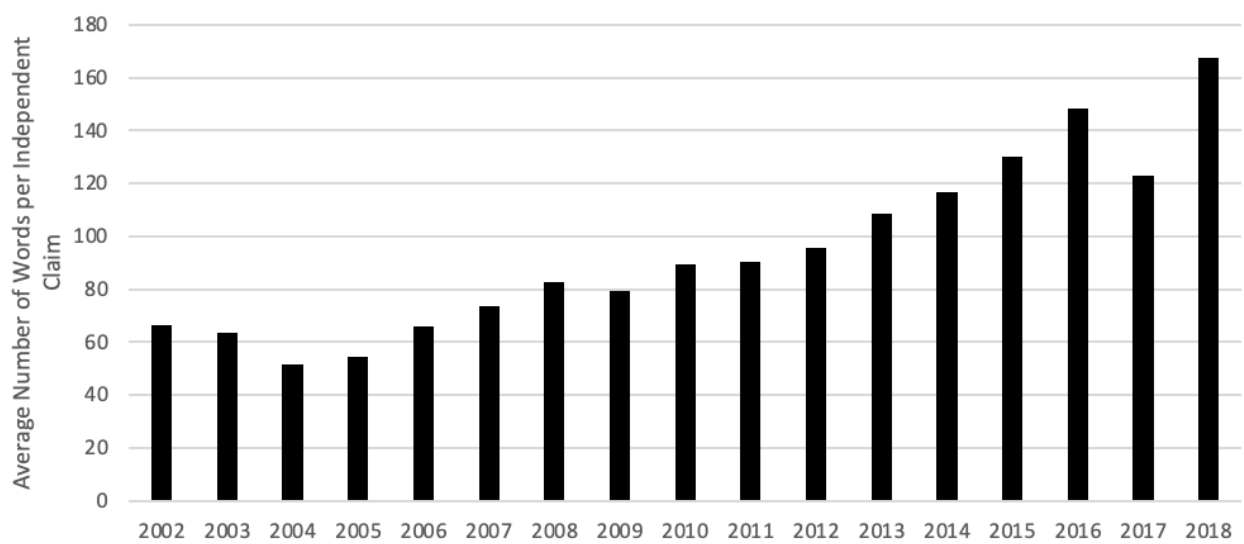

Figure 3B

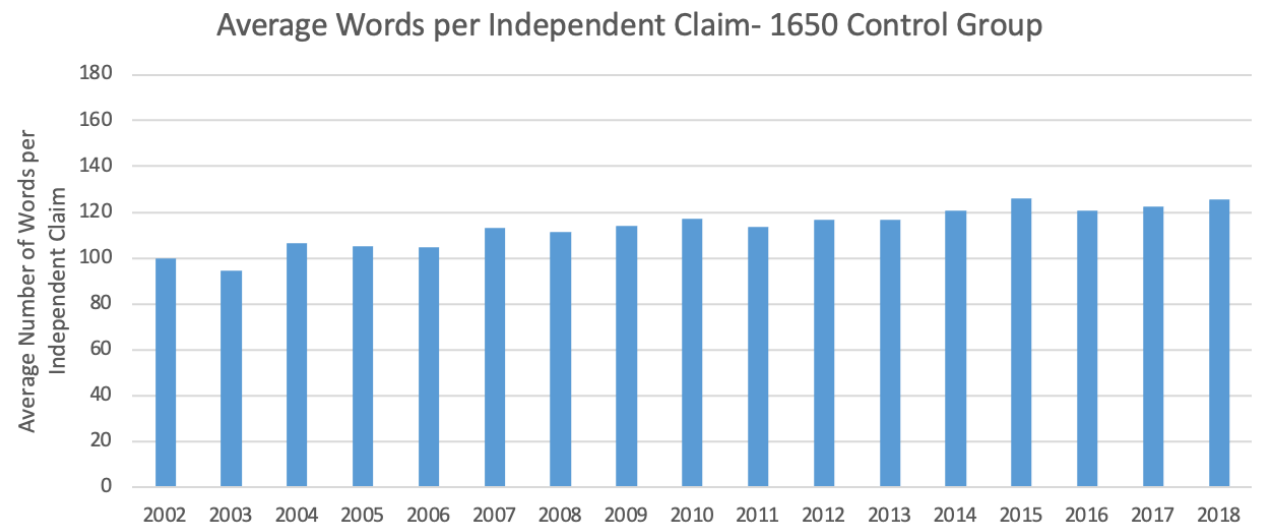

15 These data were based on the 6,407 patents from the Antibody Dataset described in Section I(A). 


\section{B. Antibody Patent Rejections}

Antibody patents differ not only from other patents in Technology Center 1600 (TC 1600), but they differ from many other technology types. We compare antibodies against all other technology centers. Additionally, we review how examiners use prior art rejections against antibody patents.

\section{Antibody Claims in Comparison to Other Technologies}

The prosecution histories and rejections used for antibody claims are different from almost every other Technology Center. ${ }^{16}$ We compared antibody patents with a first office action in 2018 against patents from all other technology centers. Figure 4 shows that antibody patents do not receive many anticipation (35 U.S.C. §102) or obviousness (35 U.S.C. \$103) rejections compared to any other Technology Centers (TC). ${ }^{17}$ Furthermore, antibody patents receive fewer indefiniteness rejections (35 U.S.C. \$112(b)) compared to TC 1600, 1700, 3600 and 3700. Finally, antibody patents receive the highest number of enablement and written description rejections (35 U.S.C. \$112(a)) with about four times as many rejections as the next highest TC.

These data show that 112(a) is the biggest hurdle to overcome antibody patents. This is surprising because for every other technology group, obviousness is the principal obstacle to receiving a patent.

Figure 4

16 Technology Center 1600 includes all patents except those from Workgroup 1640. Workgroup 1640 was excluded out because most antibody patents come from Workgroup 1640, which significantly skewed the results. See Section II (Figure 5, showing the distribution of all antibody composition of matter patents). For example, Workgroup 1640 alone represents $24 \%$ of all 35 U.S.C. $\$ 112$ (a) rejections from Technology Center 1600.

17 TC 1600 Biotechnology and Organic Chemistry; TC 1700: Chemical and Materials Engineering; TC 2100 Computer Architecture, Software, and Information Security; TC 2400 Computer Networks, Multiplex Communication, Video Distribution and Security; TC 2600 Communications; TC 2800 Semiconductors, Electrical and Optical Systems and Components; TC 3600 Transportation, Construction, Electronic Commerce, Agriculture, National Security and License \& Review; TC 3700 Mechanical Engineering, Manufacturing, Products; TC 4000 Training Academy. 


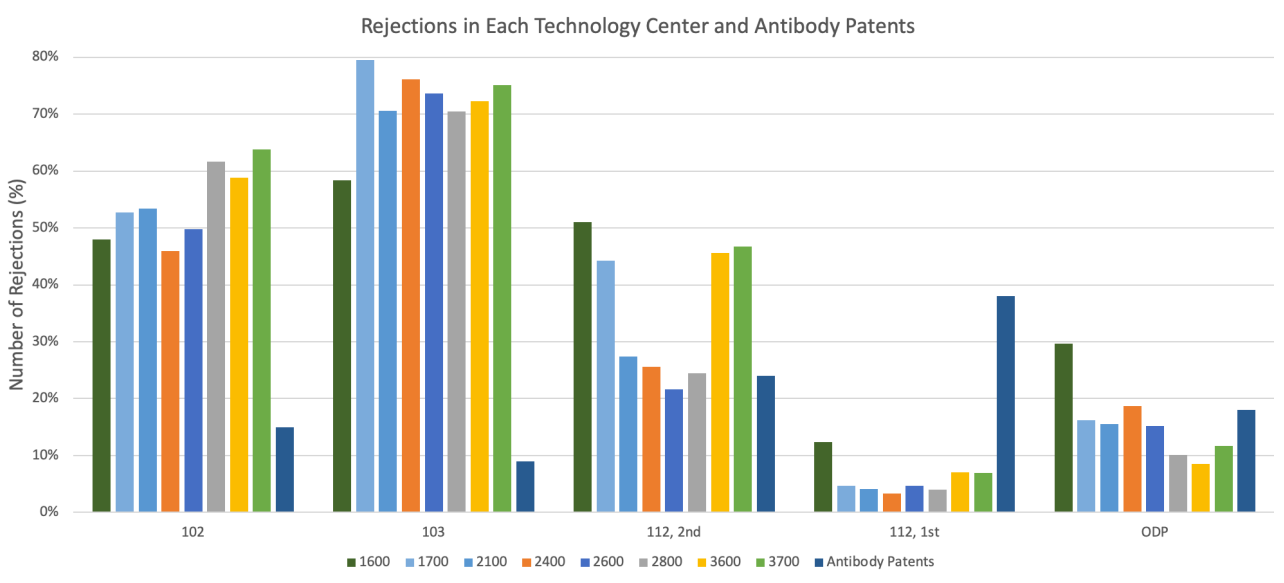

2. Other Substantive Rejections and Antibody Patents

Interestingly, as shown in Table 1 and Figure 4, antibody patents do not regularly encounter prior art rejections. Specifically, as shown in Table 1, obviousness rejections (35 U.S.C. $\S 103$ ) in the 1650 control group steadily increase to about twice the number found in the antibody group. A smaller but similar increase is seen for novelty rejections (35 U.S.C. § 102).

When compared to other patents from other technologies, antibody patents face substantially fewer prior art rejections. Other patents in Technology Center 1600, which examines patent applications in the fields of biotechnology and organic chemistry, face obviousness rejections approximately five times more frequently than antibody patents (Figure 4). This is significant because prior art rejections are usually the most difficult rejections to overcome during prosecution. ${ }^{18}$

Table $1^{19}$

\begin{tabular}{|l|l|l|l|l|}
\hline & $102-$ & $102-$ & $103-$ & $103-$ \\
& Antibody & 1650 & Antibody & 1650 \\
& Patents & Control & Patents & Control \\
\hline 2002 & 0.093 & 0.085 & 0.067 & 0.072 \\
\hline
\end{tabular}

${ }^{18}$ S. Sean Tu, Patenting Fast and Slow: Examiner and Applicant Use of Prior Art, 38 Cardozo Arts and Entertainment Law Journal 101 (2020).

${ }^{19}$ First Office Actions only. These results, however, are similar for non-final as well as Final Office Actions. 


\begin{tabular}{|l|l|l|l|l|}
\hline 2003 & 0.127 & 0.190 & 0.121 & 0.159 \\
\hline 2004 & 0.143 & 0.206 & 0.092 & 0.152 \\
\hline 2005 & 0.129 & 0.203 & 0.079 & 0.162 \\
\hline 2006 & 0.155 & 0.186 & 0.99 & 0.156 \\
\hline 2007 & 0.199 & 0.185 & 0.104 & 0.158 \\
\hline 2008 & 0.192 & 0.179 & 0.118 & 0.173 \\
\hline 2009 & 0.233 & 0.199 & 0.119 & 0.196 \\
\hline 2010 & 0.190 & 0.208 & 0.108 & 0.216 \\
\hline 2011 & 0.189 & 0.207 & 0.132 & 0.234 \\
\hline 2012 & 0.220 & 0.225 & 0.142 & 0.266 \\
\hline 2013 & 0.239 & 0.207 & 0.151 & 0.264 \\
\hline 2014 & 0.208 & 0.202 & 0.108 & 0.254 \\
\hline 2015 & 0.218 & 0.209 & 0.137 & 0.256 \\
\hline 2016 & 0.202 & 0.202 & 0.140 & 0.265 \\
\hline 2017 & 0.174 & 0.222 & 0.121 & 0.285 \\
\hline 2018 & 0.148 & 0.237 & 0.086 & 0.301 \\
\hline
\end{tabular}

Finally, as shown in Table 2, antibody patents and the 1650 control group encounter indefiniteness (35 U.S.C. § 112(b)) and obviousness-type double patenting (ODP) rejections (35 U.S.C. § 101) at approximately the same rates. These data are unsurprising because both antibody patents and 1650 control patents have fewer claims with an increasing number of patents filed per year (Figure $6 \mathrm{~A}$ and Figure 7A). The ODP rejection data suggest that applicants are filing more patents relating to the same product, which seems to be a common strategy in this sector. ${ }^{20}$

Table $2^{21}$

\begin{tabular}{|l|l|l|l|l|}
\hline & $\begin{array}{l}112(b)- \\
\text { Antibody } \\
\text { Patents }\end{array}$ & $\begin{array}{l}112(b)- \\
1650 \\
\text { Control }\end{array}$ & $\begin{array}{l}\text { ODP- } \\
\text { Antibody } \\
\text { Patents }\end{array}$ & $\begin{array}{l}\text { ODP- } \\
1650 \\
\text { Control }\end{array}$ \\
\hline 2002 & 0.107 & 0.095 & 0.013 & 0.019 \\
\hline 2003 & 0.173 & 0.242 & 0.058 & 0.056 \\
\hline
\end{tabular}

${ }^{20}$ S. Sean Tu and Mark A. Lemley, What Litigators Can Teach the Patent Office About Pharmaceutical Patents, Washington University Law Review (in press)(2021)(showing that, for litigated Orange Book patents, pharmaceutical firms file numerous "secondary" patents directed towards the same product, and that the obviousness type double patenting rejection is one of the most common rejections found for these types of patents).

${ }^{21}$ First Office Actions only. These results, however, are similar for non-final as well as Final Office Actions. 
2-Feb-22] Orange Book Patent Prosecution and Litigation

\begin{tabular}{|l|l|l|l|l|}
\hline 2004 & 0.211 & 0.258 & 0.027 & 0.069 \\
\hline 2005 & 0.176 & 0.216 & 0.035 & 0.071 \\
\hline 2006 & 0.184 & 0.216 & 0.102 & 0.070 \\
\hline 2007 & 0.178 & 0.202 & 0.083 & 0.076 \\
\hline 2008 & 0.192 & 0.195 & 0.071 & 0.092 \\
\hline 2009 & 0.183 & 0.219 & 0.119 & 0.109 \\
\hline 2010 & 0.201 & 0.232 & 0.135 & 0.121 \\
\hline 2011 & 0.231 & 0.228 & 0.105 & 0.119 \\
\hline 2012 & 0.218 & 0.246 & 0.126 & 0.132 \\
\hline 2013 & 0.205 & 0.226 & 0.171 & 0.114 \\
\hline 2014 & 0.225 & 0.228 & 0.173 & 0.133 \\
\hline 2015 & 0.233 & 0.211 & 0.177 & 0.133 \\
\hline 2016 & 0.261 & 0.215 & 0.187 & 0.146 \\
\hline 2017 & 0.225 & 0.246 & 0.153 & 0.151 \\
\hline 2018 & 0.244 & 0.267 & 0.180 & 0.182 \\
\hline
\end{tabular}

\section{Changes with Antibody Patent Prosecution Practice}

There have also been several important changes in prosecution practice that have also evolved in the past two decades. First, applicants have increased the number of antibody patents they are filing over time. Second, there has been a decrease in the number independent claims per patent over time. Finally, antibody patents are going through prosecution faster than their older counterparts.

As an initial matter $98 \%$ of the antibody patents were found in workgroup 1640. Specifically, Figure 5 shows that art units 1643 and 1644 contained the lion's share of antibody patents. Patents in workgroup 1640, are directed to "Immunology, Receptor/Ligands, Cytokines Recombinant Hormones, and Molecular Biology." Art Units 1643 and 1644 include inventions directed to "peptides or proteins, ligands or reaction products thereof" and "drug, bioaffecting and body treating compositions."

Figure 5 


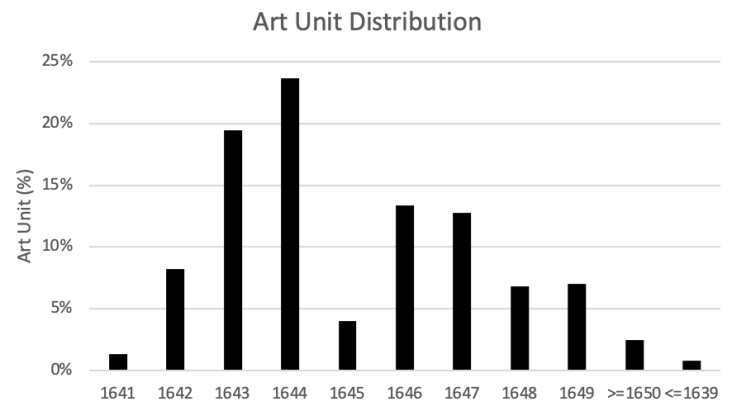

1. Increasing Number of Antibody Patents

Figure 6A shows that the number of antibody composition of matter patents has steadily risen from only about 100 granted with a first office action date in 2002 to a steady state of over approximately 500 antibody patents in 2018. ${ }^{22}$ Unsurprisingly, as antibodies became increasingly used as therapeutics, and therefore more valuable, more firms moved towards the patent system to protect their inventions. There is a similar increase in the absolute number of patents in the 1650 control group. However, in the 1650 control group we only see a two-fold increase in the number of patents, while there is a fivefold increase in the antibody group.

Figure 6A

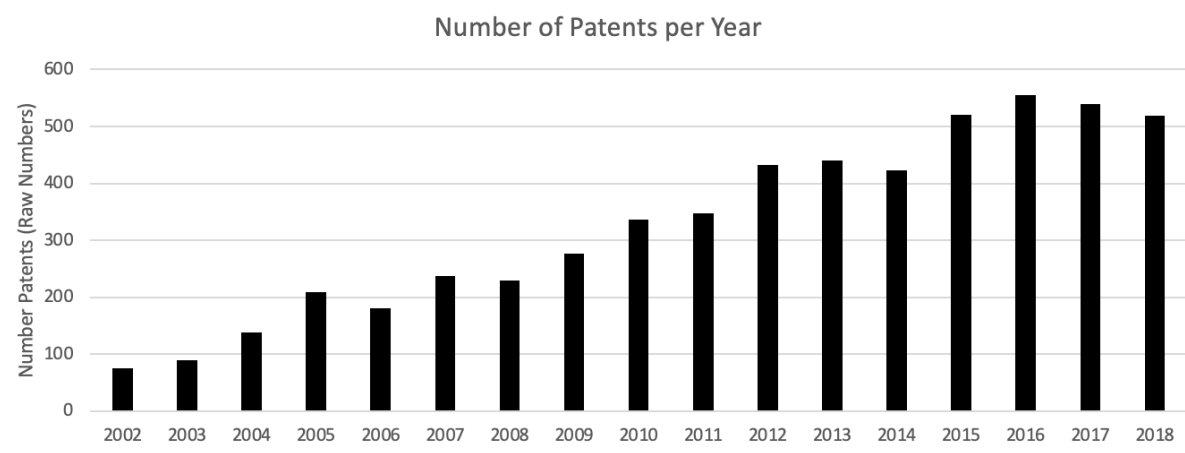

Figure 6B

${ }^{22}$ These data were based on the 6,407 patents from the Antibody Dataset described in Section $\mathrm{I}(\mathrm{A})$. 


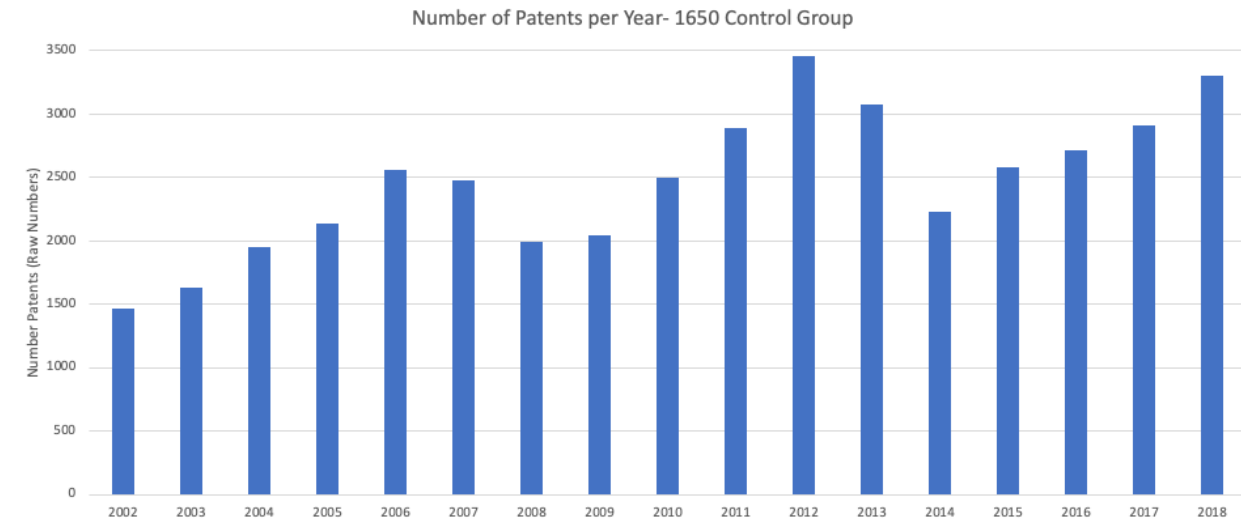

2. Fewer Claims Over Time

As shown in Figure 7A, the number of independent claims in those patents has decreased from an average of about 3.5 claims in 2002 to just over 2 claims in 2018. ${ }^{23}$ Thus, currently more patents are being granted with fewer independent claims. As shown in Figure $7 \mathrm{~B}$, we note that the number of independent claims also are reduced in the 1650 control group, however, the magnitude of the change is less dramatic, moving from approximately 2.5 independent claims in 2002 to just over 1.5 independent claims in 2018.

Figure 7A

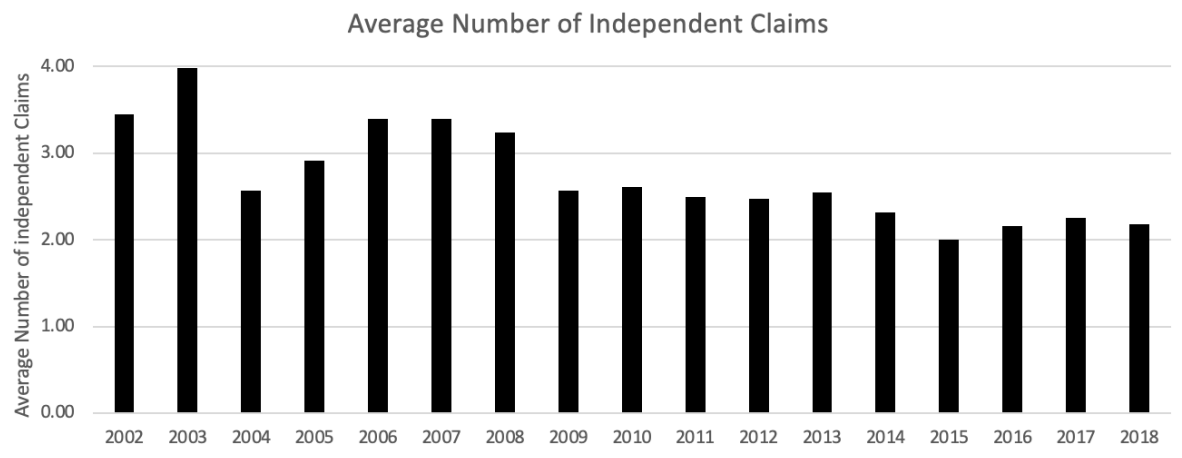

Figure 7B

${ }^{23}$ These data were based on the 6,407 patents from the Antibody Dataset described in Section I(A). 
Average Number of Independent Claims- 1650 Control Group

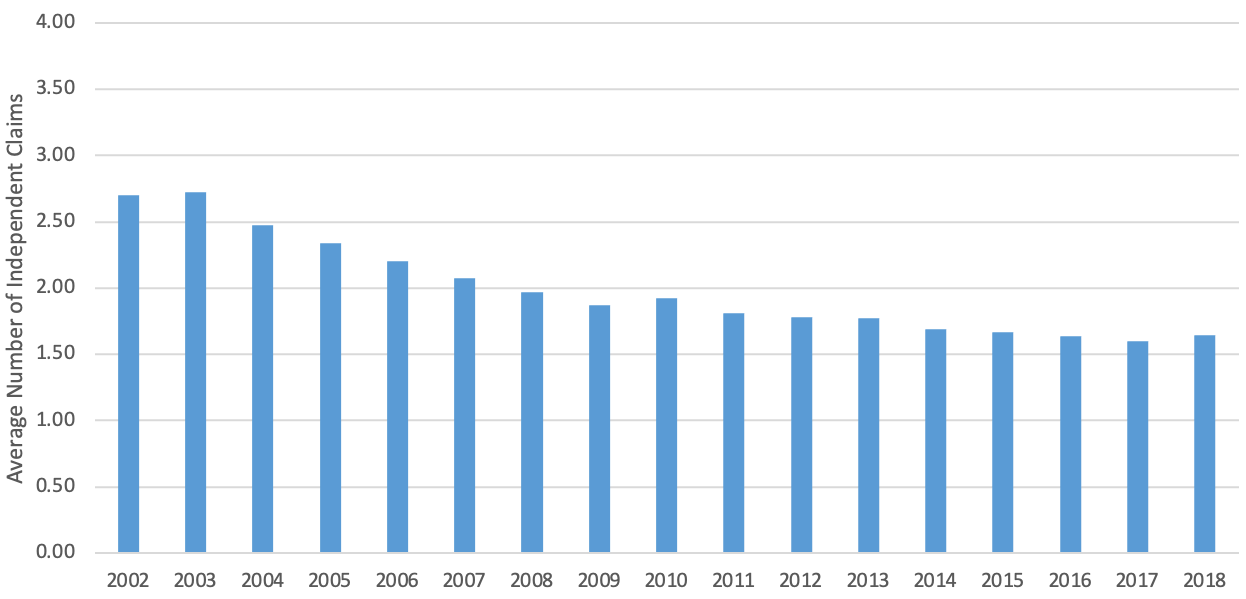

3. Fewer Original Patent Filings Over Time Compared to the 1650 Control

As shown in Figure 8A, more "original" patents were granted over time. ${ }^{24}$ An "original" patent is defined as a patent that does not claim priority to another patent. Specifically, in 2002-2005 only approximately $30 \%$ of granted patents were original filings. However, by 2009-2018 the number of granted patents that were original filings increased to about $50 \%$. In contrast, both divisional (DIV) and continuation (CON) patents, for the most part, stayed at approximately $20-25 \%$ while continuation-in-part (CIP) patents stayed at around 5\% throughout 2006-2018.

In contrast, Figure 8B shows that, for the 1650 control, the number of granted patents that were original filings stayed at around $60 \%$ through 2002-2018. Additionally, DIVs and CONs stayed at around $15-20 \%$ while CIPs also stayed at around 5\%.

Figure 8A

${ }^{24}$ These data were based on the 6,407 patents from the Antibody Dataset described in Section I(A). 
2-Feb-22] Orange Book Patent Prosecution and Litigation

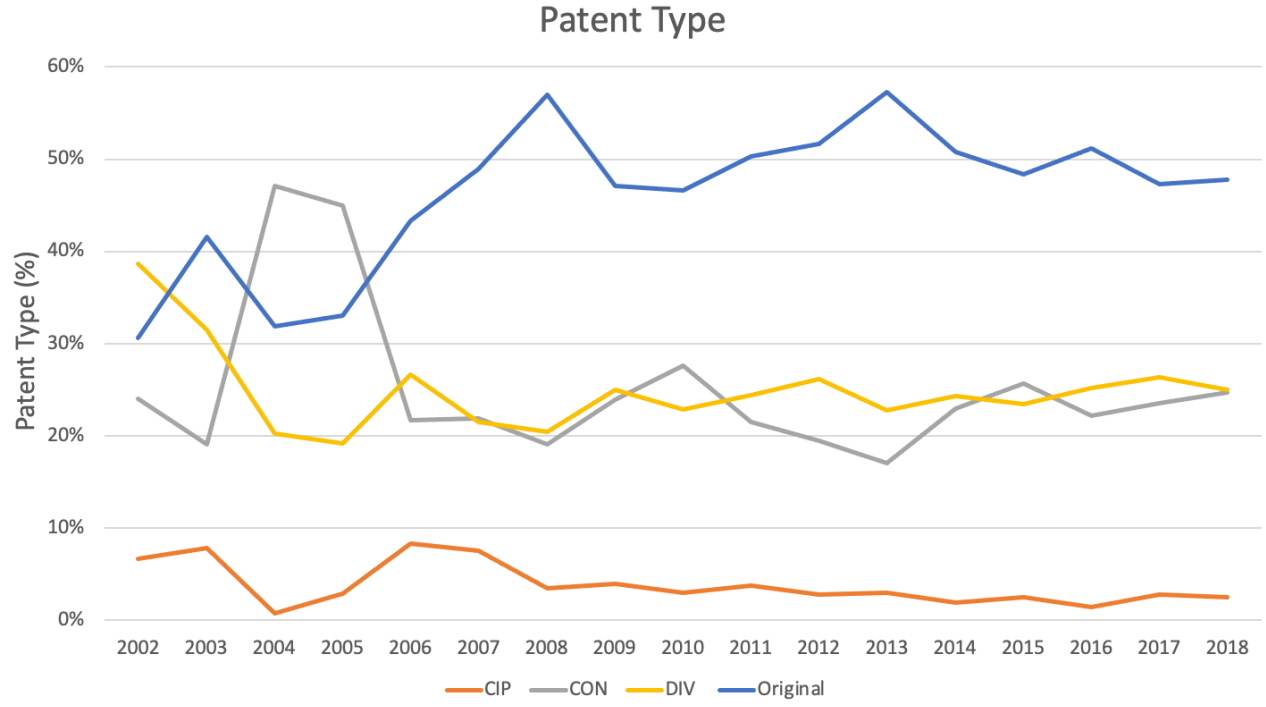

Figure 8B

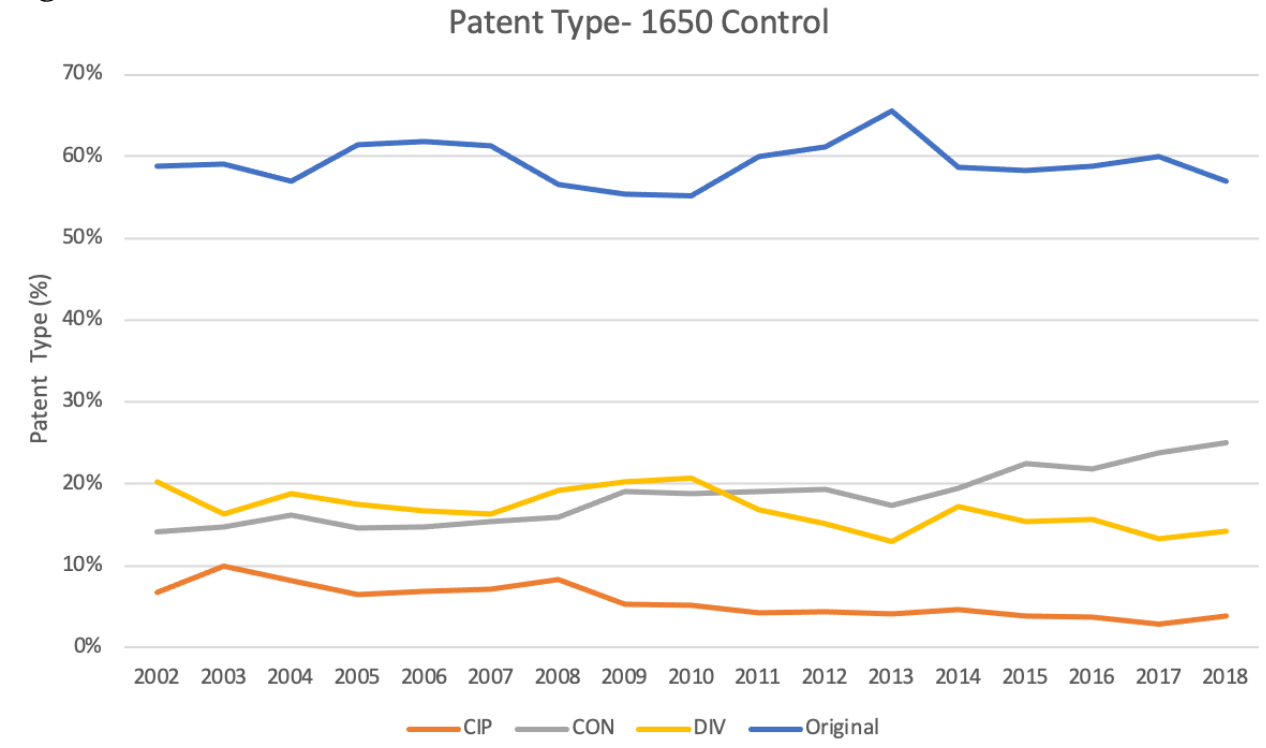

Table 3 shows the overall data where the data is not segmented by year. Additionally, Table 3 includes the percentage of applications with restriction requirements. These data show that antibody patents claim priority to another application and have fewer original patents compared to the 1650 control group. Although the antibody dataset has more divisional patents, they experience about the same number of restriction requirements as the 1650 control group. 
Table 3

\begin{tabular}{|l|l|l|}
\hline & $\begin{array}{l}\text { Antibody } \\
\text { Dataset }\end{array}$ & 1650 Control \\
\hline Continuing Applications 25 & $52 \%$ & $41 \%$ \\
\hline Continuation-in-Part Patents & $3 \%$ & $5 \%$ \\
\hline Continuation Patents & $25 \%$ & $20 \%$ \\
\hline Divisional Patents & $24 \%$ & $16 \%$ \\
\hline Original Patents & $48 \%$ & $59 \%$ \\
\hline Restriction Requirements & $67 \%$ & $63 \%$ \\
\hline
\end{tabular}

\section{Shorter Patent Prosecution Duration Over Time}

The patent prosecution profile has also changed for antibody patents over time. First, as shown in Figure 9A, the number of office actions per patent has decreased from approximately 2.5 in the early 2000 's to only 1.2 office actions per patent in 2016-2018. In contrast, as shown in Figure 9B, the number of office actions in the 1650 control group remains relatively steady at 1.8 office actions per patent throughout the 2002-2018 timeframe. ${ }^{26}$ Thus, the back-andforth negotiations between the examiner and the applicant for antibody patents are far fewer now than two decades ago.

Figure 9A

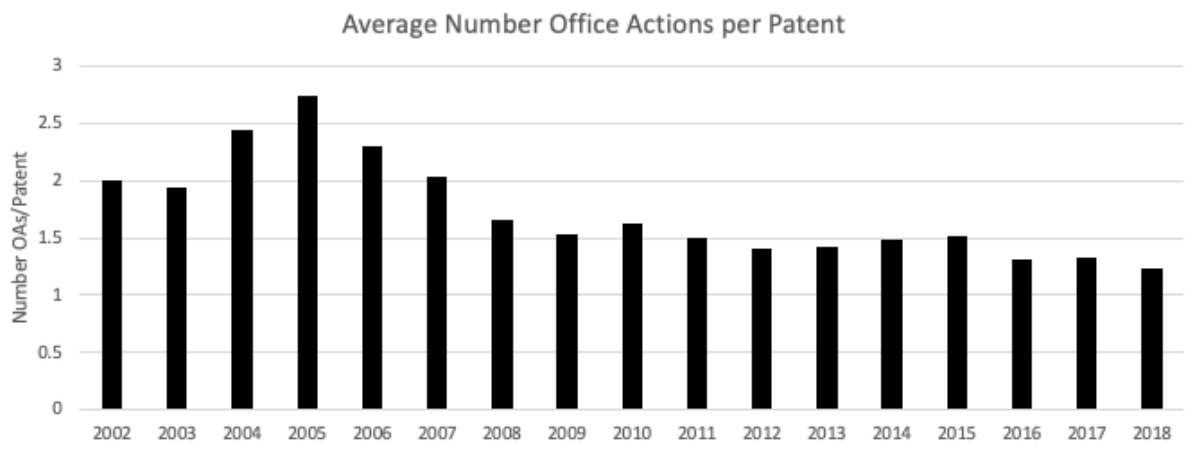

25 A "continuing application" is a continuation, divisional, or continuation-in-part application. See also MPEP $\$ 201.02$.

${ }^{26}$ The number of Office Actions per Grant corresponds to the Office Action per Grant Ration (OGR score). See S. Sean Tu, Three New Metrics for Patent Examiner Activity: Office Action per Grant Ratio (OGR), Office Actions per Disposal Ratio (ODR), and Grant Examiner Ratio (GER), 100 Journal of the Patent and Trademark Office Society 277 (2018); S. Sean Tu, Bigger and Better Patent Examiner Statistics. 59 IDEA 309 (2018). 
Figure 9B

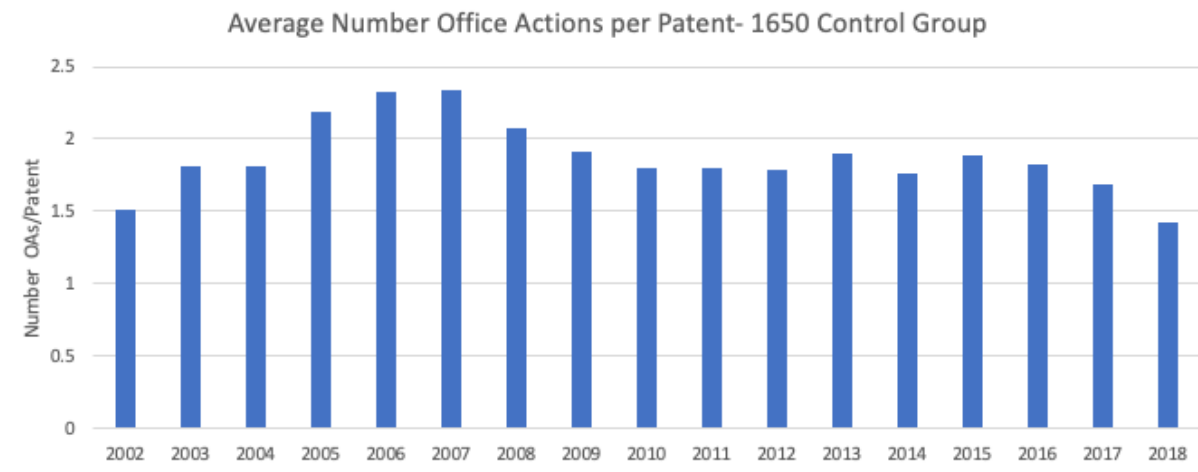

This naturally corresponds to the duration of prosecution. Figure 10A shows that in the early 2000's patent prosecution would customarily take about 2.5 years and fell to about only 1.2 years from 2016-2018. There is a similar decrease in patent prosecution duration in the 1650 control group, shown in Figure 10B. However, the magnitude of this decrease is much smaller, moving from about 1.8 years to 1.5 years.

Figure 10A

Duration between First Office Action and Issue Date

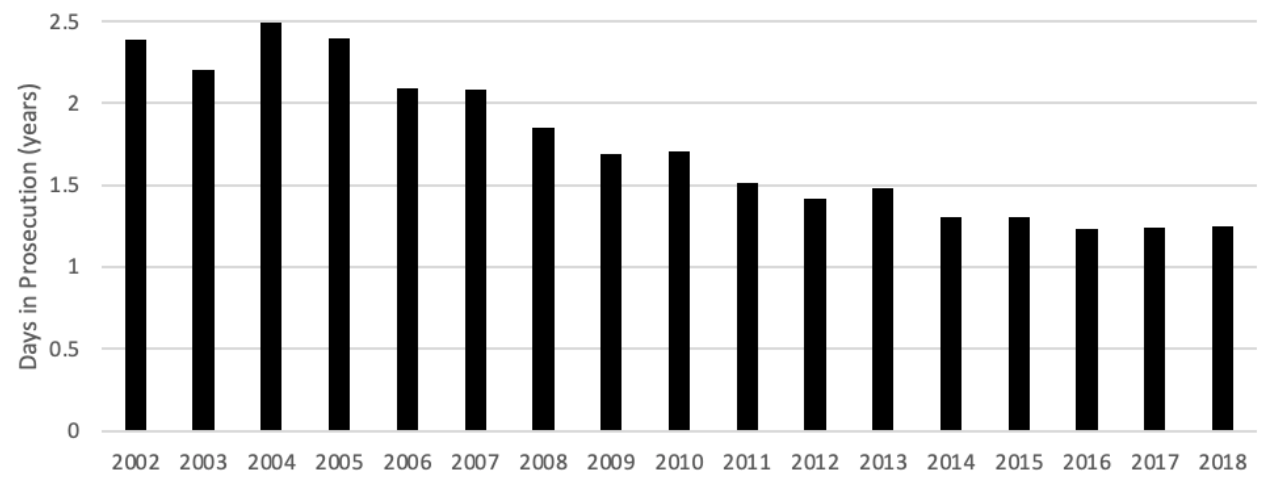

Figure 10B 


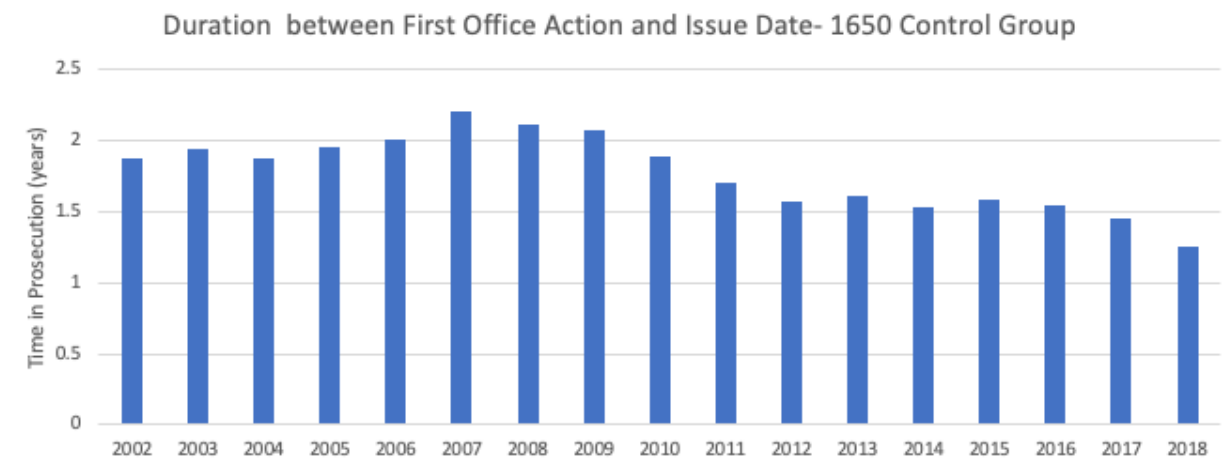

\section{DISCUSSION}

The caselaw around antibody patents, specifically around the written description and enablement requirements, has evolved in the past two decades. ${ }^{27}$ The PTO has attempted to track the changes in caselaw with their own guidance around antibody patents. In this section, we interpret the empirical results by placing these results in the context of the time-dependent PTO policy and Federal Circuit caselaw on antibody patents. ${ }^{28}$

\section{A. Change in Claim Type}

The increase in 112(a) rejections faced during prosecution supports the idea espoused by Judge Lourie, specifically that " $[w]$ hat is new today is not the law, but generic claims to biological materials that are not fully enabled." 29 These data are also consistent with

${ }^{27}$ See S. Sean Tu and Christopher Holman, Antibody Claims and the Evolution of the Written Description and Enablement Requirement, IDEA (in press, 2022) for a complete discussion of the historical changes in PTO policy and Federal Circuit jurisprudence on antibody patents.

${ }^{28}$ See S. Sean Tu and Christopher Holman, Antibody Claims and the Evolution of the Written Description and Enablement Requirement, IDEA (in press, 2022) for a complete discussion of the historical changes in PTO policy and Federal Circuit jurisprudence on antibody patents.

${ }^{29}$ Amgen Inc. v. Sanofi, Aventisub LLC, 850 F. App'x 794, 795 (Fed. Cir. 2021) (also stating that, "in order to have invented a genus, one needs to have invented species that constitute the genus. Drawing a broad fence around subject matter, without filling in the holes, is not inventing the genus. It in fact discourages invention by others. If one has disclosed or enabled only a small number of invented species, then one has not invented a broad genus. Invention of a genus means to conceive and reduce to practice a reasonable number and distribution of species constituting the genus. Mere statement of a genus does not demonstrate that one has invented a generic concept, without the enablement of 
findings by other commentators that non-ANDA pharmaceutical patents face higher invalidation rates based on 112(a) during litigation. ${ }^{30}$

Applicants have changed from broad genus claims defined by the antigen alone to narrower claims defined by the antibody's own structure (Figure 2). Below we describe the evolution of these claims and develop a hypothesis of how the changing nature and uses for antibodies resulted a shift in antibody claiming practice.

\section{Early Antibody Claims: Antibody Claims Defined by Antigen Structure Only}

During this period monoclonal antibodies were mainly used as research and diagnostic tools and not as therapeutic agents. These mouse antibodies were only used to determine if an antigen was present or absent, it did not matter where the antibody bound, i.e., what the specific epitope was, nor the type of antibody, it only mattered if the antibody bound the antigen or did not bind to the antigen.

This binary decision (binding vs. not binding) was consistent with broad patent protection based on antigen structure alone because, during this time period, the value of the antibody rested primarily in the antibody's ability to bind and detect the antigen. Accordingly, during this early phase in monoclonal antibody development, an applicant could receive a patent by simply characterizing the antigen (without giving any structural elements of the antibody itself). ${ }^{31}$

constituent species.”)

30 John R. Allison \& Lisa Larrimore Ouellette, How Courts Adjudicate Patent Definiteness and Disclosure, 65 Duke Law Journal 609, 666 (2016) (Table 7 showing that non-ANDA pharmaceutical patents are the worst performers on written description of any industry); see also Jackob S. Sherkow, Describing Drugs: A Response to Professors Allison and Ouellette, 65 Duke Law Journal 127, 128 (2016). Cf. Dmitry Karshtedt, Mark A. Lemley, and Sean B. Seymore, The Death of a Genus Claim, 35 Harvard Journal of Law and Technology (in press 2021) (showing that only a small minority of Federal Circuit decisions have upheld a genus claim in the chemical industry over the past thirty years).

${ }^{31} \mathrm{~S}$. Sean Tu and Christopher Holman, Antibody Claims and the Evolution of the Written Description and Enablement Requirement, IDEA (in press, 2022); see also PTO Written Description Training Materials 2008 revisions, Example 13. 66 Fed. Reg. at 1106 (2001). 
As shown in Figure 1, during this early stage, 112(a) was not used frequently to reject antibody patents. Additionally, as shown in Figure 2, during this time period the majority of these antibodies were claimed by describing only the antigen. These genus claims did not define the antibody structurally, but instead by antigen that the antibody could bind to specifically. The patentee was only required to disclose the antigen's structure. The resulting broad scope of antibody claims made sense during this period of antibody development because antibodies were being used primarily as research or diagnostic tools.

Example 1 is typical of an antibody patent during this timeframe. No antibody structure is given in the ' 800 patent. The antibody is only defined by the antigen (SEQ ID NO: 9). This claim is relatively short (only eighteen words) because it defines the antibody only by the antigen that it binds.

Example 1- US Patent No. 7,060,800

Claim 1: An isolated antibody or antigen binding fragment thereof, which specifically binds to a polypeptide of SEQ ID NO:9.32

2. Replacing Broad Genus Claims: Antibody Claims Defined by Antibody Complementarity Determining Regions (CDRs)

During this period monoclonal antibodies began to be used as therapeutic agents, however they faced many issues due to the human anti-mouse antibody (HAMA) response. ${ }^{33}$ Accordingly, these early therapeutics suffered major setbacks at the FDA and often times did not work well as human medicines. ${ }^{34}$

The PTO and courts narrowed claims due to the new therapeutic uses for antibodies as well as the realization that binding to different epitopes could have dramatically different functional

\footnotetext{
${ }^{32}$ SEQ ID NO:9 is a human TNF-x protein that is 228 amino acids.

${ }^{33}$ These negative effects are based on the fact that the human body recognizes the mouse antibody as foreign; see also Appendix 1 for deeper discussion of HAMA response.

${ }^{34}$ See for example, Nadim Mahmud, Dusko Klipa, and Nasimul Ahsan, Antibody Immunosuppressive Therapy in Solid-Organ Transplant, 156 mAbs 148, 151 (2010)(showing that OKT3's "adverse effects proved to be consistently problematic.").
} 
effects on the body. Courts began to apply a stricter version of the Lilly written description requirement requiring applicants to describe their antibodies using structure instead of function. ${ }^{35}$ Antibody claims changed as the PTO and courts began to reject and invalidate claims based only on antigen structure. Accordingly, during this time period examiners began using 112(a) more frequently to reject antibody claims that were directed towards genus claims and started forcing applicants to define antibody structures.

In response to these rejections, applicants moved towards claims that specifically defined the antibody based on structural elements. ${ }^{36}$ These claims usually focused on the CDRs, which are the antibody structural elements that define the binding site of the antibody to antigen. ${ }^{37}$ There are six CDRs for each antigen receptor that can come into contact with the antigen. Each CDR binding site is usually defined by 3-15 amino acids. Thus many antibody claims during this time period require at least 50-60 amino acids spread among the 6 CDRs (usually 6 individual SEQ IDs).

Example 2 is a typical antibody claim during this timeframe. The antibody CDRs are now given as the key structural elements that define the invention. These CDRs, however, are based on relatively short amino acid sequences. Accordingly, even with defined CDR structural elements, these antibody claims still can be broad.

Example 2- US Patent No. 9,353,181

Claim 1: An isolated IL-23p19 antibody, comprising a light chain variable region and a heavy chain variable region, said light chain variable region comprising: a complementarity determining region light chain 1 (CDRL1) amino acid sequence of SEQ ID NO:50; a CDRL2 amino acid sequence of SEQ ID NO:56; and a CDRL3 amino acid sequence of SEQ ID NO:73,

\footnotetext{
${ }^{35}$ Christopher M. Holman, Is Lilly Written Description a Paper Tiger: A Comprehensive Assessment of the Impact of Eli Lilly and Its Progeny in the Courts and PTO, 17 Alb. L.J. Sci. \& Tech. 1 (2007).

${ }^{36}$ See Figure 2.

37 CDRs are the crucial antibody structural elements that confer antibody specificity. See also Appendix 1 for Antibody Technology primer.
} 
said heavy chain variable region comprising: a complementarity determining region heavy chain 1 (CDRH1) amino acid sequence of SEQ ID NO:5; a CDRH2 amino acid sequence of SEQ ID NO:28; and a CDRH3 amino acid sequence of SEQ ID NO:44. ${ }^{38}$

3. Narrow Species Claims: Antibody Claims Defined by Complete Antibody Structure

Presently, many antibodies are defined by both their variable and framework regions. Accordingly, most antibody claims currently include an almost complete description of the entire antibody structure, and not just the CDR regions.

The current state of monoclonal antibody technology relies on chimeric antibodies and antibody "humanization" to overcome the deleterious effects of the HAMA response. By using recombinant DNA, scientists can now create an antibody that is mostly (or entirely) human. These chimeric and humanized antibodies are used for therapeutic purposes. Thus, for humanized antibodies both the CDR structure as well as the framework structures are important. Unlike previous antibody iterations, however, the DNA structures are known for humanized antibodies. Accordingly, the primary structure of these antibodies can be well defined.

Example 3 is a typical antibody claim during this timeframe. The claim contains an almost complete antibody structure. Both the heavy and light chains are structurally defined. Additionally, the amino acid sequences given are between 112-122 amino acids long. Furthermore, this antibody has the functional requirement of being "neutralizing." Thus, these claims are much narrower because the structure of antibody is defined with much more specificity and includes additional functional requirements.

Example 3- US Patent No. 10,822,397

Claim 1: An isolated antibody or epitope-binding fragment thereof that specifically binds to at least one

\footnotetext{
${ }^{38}$ SEQ ID NOs 50, 56, 73, 5, 28 and 44 are 14, 7, 11, 5, 17, and 8 amino acids in length, respectively.
} 
2-Feb-22] Orange Book Patent Prosecution and Litigation

conformational (non-linear) epitope of enterovirus 71 (EV71), wherein the antibody comprises at least one variable light chain and at least one variable heavy chain, wherein the variable light chain comprises an amino acid sequence comprising the amino acid sequence set forth in SEQ ID NO: 3, and wherein the variable heavy chain comprises an amino acid sequence comprising the amino acid sequence set forth in SEQ ID NO: 4 or SEQ ID NO: 5, wherein the antibody or epitope-binding fragment thereof is neutralizing. ${ }^{39}$

\section{B. Increasing Use of 112(a)}

We find that antibody examiners have increased the use of 112(a) to reject antibody patents since 2006 (Figure 1A). ${ }^{40}$ Additionally, 112(a) is the major hurdle that applicants must overcome before receiving an antibody patent (Figure 4$).{ }^{41}$

Beginning in 2006, patent examiners were ignoring their own PTO written description guidelines by increasingly applying a more stringent 112(a) standard. 42 This more stringent standard was being applied even when courts had specifically upheld the PTO's written description antibody guidelines. ${ }^{43}$

${ }^{39}$ SEQ ID NOs 3, 4 and 5 are 112, 122, and 119 are amino acids in length, respectively.

${ }^{40}$ See Figure 1A (showing an almost 100\% increase in the use of 112(a) from 2006 to 2018).

${ }^{41}$ See Figure 4 (showing that antibody patents experience 10-fold more 112(a) rejections compared with any other technology center. Additionally showing that 112(a) is the major obstacle to obtaining an antibody patent compared with other technology centers where 103 rejections are the primary obstacle.)

${ }^{42}$ Written Description Training Material, Revision 1, March 25, 2008. (Example 13, showing that a claim directed towards "An isolated antibody capable of binding to antigen X" can satisfy the written description requirements of 35 U.S.C. §112); we note that our data does not distinguish between the written description or enablement guidelines. However, this is consistent with the 2008 written description guidelines put out by the PTO because it would be illogical to put out a guidance that gives an example that satisfies the written description requirement while simultaneously failing the enablement requirement (without specifically stating that in the guidelines).

${ }^{43}$ See Enzo Biochem v. Gen-Probe, Inc., 323 F.3d 956, 964 (Fed.Cir. 2002) (stating "[we] are persuaded by the Guidelines on this point and adopt the PTO's applicable standard for determining compliance with the written description requirement."); Noelle v. Lederman, 355 F.3d 1343, 1349 (Fed. Cir. 2004)(in holding no interference-in-fact "[t]he court adopted the USPTO Guidelines as persuasive authority for the proposition that a claim directed to 
We argue that patent examiners were able to look beyond caselaw and consider the intent of 112(a) through the lens of how the technology was being used. Accordingly, patent examiners from 2006-2018 were applying 112(a) in a manner that was contrary to the PTO training materials. ${ }^{44}$ Interestingly, both the courts and the PTO ended up concurring with patent examiners, however this concurrence took over a decade and came once the issue was squarely before the court.

Why have patent examiners been applying a different standard than what was expected from the PTO training guidelines and legal precedent? We believe it is because examiners were following the science and advances in antibody technology. Patent examiners are trained scientists and not trained lawyers. ${ }^{45}$ We find that in Technology Center 1600,30\% of examiners have masters degrees and $62 \%$ have Ph.D.s in some natural science degree. ${ }^{46}$ In contrast, most examiners do not have a traditional legal education, with only approximately $15 \%$ having a J.D. ${ }^{47}$

By 2018, the PTO ended up conforming with examiners and repealing its previous guidance stating that, "[Example 13 of the

\footnotetext{
'any antibody which is capable of binding to antigen $\mathrm{X}$ ' would have sufficient support in a written description that disclosed 'fully characterized antigens."'); Centorcor Ortho Biotech, Inc. v. Abbott Labs, 636 F.3d 1341, 1351-2 (2011)(stating that "an applicant can claim an antibody to novel protein $\mathrm{X}$ without describing the antibody when (1) the applicant fully discloses the novel protein and (2) generating the claimed antibody is so routine that possessing the protein places the applicant in possession of an antibody.").

${ }^{44}$ Written Description Training Material, Revision 1, March 25, 2008 (repealed in 2018).

${ }^{45}$ All examiners are required to have a science degree in their field. Accordingly, $100 \%$ of patent examiners will have a Bachelor of Science degree, however, many examiners have also obtained graduate degrees. See also, https://www.uspto.gov/jobs/become-patentexaminer (visited November 21, 2021).

${ }^{46}$ See also S. Sean Tu, Paul R. Gugliuzza, and Amy Semset, Overqualified and Underrepresented: Gender Inequality in the Pharmaceutical Patent Field, (in manuscript, 2022)(Table 2, showing the different education levels of examiners. Showing that the majority of examiners in 1600 have doctorate degrees, while about $15 \%$ have juris doctorate degrees).

${ }^{47}$ See also S. Sean Tu, Paul R. Gugliuzza, and Amy Semset, Overqualified and Underrepresented: Gender Inequality in the Pharmaceutical Patent Field, (in manuscript, 2022)(Table 2, showing the different education levels of examiners. Showing that the majority of examiners in 1600 have doctorate degrees, while less than $15 \%$ have juris doctorate degrees). Examiners are trained extensively in patent law during their first six months in the PTO training academy.
} 
2008 Written Description Training Materials]...should not be used in determining whether there is adequate written description under 35 U.S.C. \$112(a) for a claim drawn to an antibody." 48 Although it took over a decade for the courts and PTO to catch up with patent examiners, both the Federal Circuit and the PTO now espouse the same standards that patent examiners were applying for over a decade.

\section{Narrowing Claim Scope}

The number of words in each claim is important because previous studies have shown that increasing word counts in a claim correlates with narrower scope. ${ }^{49}$ We find a three-fold increase in the number of words in independent claims for antibody patents. Specifically, there was an increase from 60 to approximately 180 words per independent claim. (Figure 3A) This is unsurprising because the most common ways to traverse a 112(a) rejection is to simply make claim amendments. ${ }^{50}$ Claim amendments almost always require the applicant to add words.

These data also match the general trends that we identify where patent examiners initially allowed broad claims in the early development of antibody technology (which requires few words) and then changing to only allow narrow claims as therapeutic antibodies were developed (which requires many more words to describe all six CDRs or the complete heavy and light chains). For instance, Example 1 is relatively short and has only eighteen words. In contrast, Examples 2 and 3 have five times more words with 96 and 97 words respectively. The increase in the number of words combined with the fact that antibodies are now being defined by

\footnotetext{
${ }^{48}$ USPTO February 22, 2018 memo from Robert W. Bahr, Deputy Commissioner for Patent Examination Policy, "Clarification of Written description Guidance for Claims Drawn to Antibodies and Status of 2008 Training Materials."

49 Jeffrey M. Kuhn and Neil Thompson, How to Measure and Draw Causal Inferences with Patent Scope, 26 International Journal of the Economics of Business 5 at 6 (2019)(showing that "a patent's scope can be measured by counting the number of words in its first claim, with more words corresponding to less scope.").

${ }^{50}$ S. Sean Tu, Patenting Fast and Slow: Examiner Rejections and Applicant Traversals to Nonprior Art Rejections, 2021 Mich. St. L. Rev 411 (2021) (Figure 7 showing the most common response to either a written description or enablement rejection are claim amendments).
} 
their structure (instead of their antigen) suggests a much narrower antibody claim today compared to 2002.

We show that applicants are obtaining more and more antibody patents over time, we find a five-fold increase in antibody patents over the course of this seventeen-year period. Of course, this correlates with the ever-increasing importance of biologics as therapeutics. Although applicants are filing more patents, there are fewer claims per patent and those claims are much narrower in scope.

Additionally, we find that more and more of these patents are coming from the same family of patents as outlined by the ten-fold increase in ODP rejections, which can only be used against patents within the same family (Table 2). ${ }^{51}$ These data argue that many of these patents are directed to the same antibody product or have relevant family members.

Similar to putting together a jigsaw puzzle with only half the pieces, firms could be cobbling together many narrow patents to try and achieve the same broad patent scope that they were previously able to attain with one genus patent. ${ }^{52}$ See, for example the Humira family of patents, which purportedly contains over 150 patents covering similar products. ${ }^{53}$ Many of these patents contain antibodies that have been defined by different CRDs or by their heavy and light chain framework regions.

\footnotetext{
${ }^{51}$ A patent in the "same family" would be defined by the presence of an ODP rejection which requires: (1) a common inventor or owner and (2) the application at issue must be obvious in view of the subject matter claimed and (3) no restriction requirement that resulted in the subject matter at issue being pursued in a separate divisional application. See MPEP $\S 804$.

${ }^{52}$ See for example the Humira Patent family with over 100 associated patents. See also Jeffrey Wu \& Claire Wan-Chiung Cheng, Into the Woods: A Biologic Patent Thicket Analysis, 19 Chicago Kent J. Intell. Prop 93, 130. (2021) and Rachel Moodie and Bernard Chao, Biological Patent Thickets and Delayed Market Access to Biosimilars, An American Problem, (2022, in manuscript).

${ }^{53}$ See for example Humira patents: U.S. 8,414,894 (claim 61, 68, 76, defining both the LCVR and HCVR); and U.S. 8,372,401 (claim 1 defining an almost complete heavy and light chain region). See also Jeffrey Wu \& Claire Wan-Chiung Cheng, Into the Woods: A Biologic Patent Thicket Analysis, 19 Chicago Kent J. Intell. Prop 93, 130. (2021)(Table 5, finding more than 154 patents associated with the Humira antibody product). Rachel Moodie and Bernard Chao, Biological Patent Thickets and Delayed Market Access to Biosimilars, An American Problem, (2022, in manuscript).
} 
Some commentator have expressed concern that large patent thickets have delayed biosimilar market entry. ${ }^{54}$ Others argue that the pendulum has swung too far, and that applicants are now inappropriately being denied genus claims. ${ }^{55}$ It is possible that innovators have responded to the narrowing scope of antibody patents by obtaining a larger number of patents with relatively narrow claims.

\section{Speeding Up Prosecution}

In 2002, antibody patents took about 30 months to go through prosecution, but that time has been reduced to only 14 months in $2018 .{ }^{56}$ Correspondingly, the number of office actions required to obtain a patent was also cut in half over this seventeen-year period. The overall patent pendency at the PTO has decreased from 31 months to about 24 months since 2013. In contrast, there is an increase in pendency from 23 to 25 months for patents in TC 1600 over the past two years. ${ }^{57}$ Thus, antibody patents seem to be moving through the patent office much faster than other patents. ${ }^{58}$

Thus, the back-and-forth negotiations between the examiner and the applicant for antibody patents are far fewer now than two decades ago. This could be because the claims are much narrower and thus require fewer limitations since applicants have already started with antibody claims that give structure and are narrower in scope. Additionally, these data suggest that both applicants and examiners understand what is required to overcome the written

\footnotetext{
${ }^{54}$ Rachel Moodie and Bernard Chao, Biological Patent Thickets and Delayed Market Access to Biosimilars, An American Problem, (2022, in manuscript)(Figure 1 showing that the US biologic market creates large patent thickets. Where the US asserts 377 patents covering 30 biosimilars, Canada and the United Kingdom only assert 46 and 24, respectively for those same 30 biosimilars); see also Jeffrey Wu \& Claire Wan-Chiung Cheng, Into the Woods: A Biologic Patent Thicket Analysis, 19 Chicago Kent J. Intell. Prop 93. (2021)

${ }^{55}$ Dmitry Karshtedt, Mark A. Lemley, and Sean B. Seymore, The Death of the Genus Claim, 35 Harvard Journal of Law and Technology (2022, forthcoming). Cf. Christopher M. Holman, Is the Chemical Genus Claim Really "Dead" at the Federal Circuit?: Part I, Biotechnology Law Report (in manuscript, 2022).

${ }^{56}$ See Figure 10 above.

${ }^{57}$ See https://www.uspto.gov/dashboard/patents/total-pendency-by-tc.html

${ }^{58} \mathrm{We}$ note that the 1650 control group also exhibited a decrease in prosecution time from approximately 24 to 18 months. However, this decrease is significantly less than the 16 month decrease from 30 to 14 months exhibited for antibody patents.
} 
description and enablement standards. In contrast, the earlier patents filed in the early 2000's had broad scope and likely needed more rounds of prosecution to narrow the scope of the claims. ${ }^{59}$

These data also show that antibody patents receive fewer anticipation and obviousness rejections. ${ }^{60}$ It is likely that we see fewer prior art rejections because these very narrow claims are truly novel and non-obvious over the prior art, especially if they contain both structural and functional requirements. Typically, anticipation and obviousness rejections based on prior art are the most difficult and time consuming to overcome. ${ }^{61}$ Thus, patent claims that do not face these rejections can move through prosecution faster.

\section{IMPROVING ANTIBODY PATENT PROSECUTION62}

Antibody technology has radically advanced within the last 30 years. Revolutionary changes in antibody technology have moved antibodies from research tools to diagnosis to treatment of diseases. Current antibody technology now allows researchers to create consistent and highly specific antibodies that can not only treat diseases, but treat disease without many of the key side effects previously common to these drugs. While the uses for antibodies have increased, the numbers of patents filed towards antibodies have commensurately increased. Courts, the USPTO administration and patent examiners have all responded. Interestingly, however, they have not all moved in the same direction at the same pace.

The USPTO administration, patent examiners, and courts have all taken notice of these scientific advances and have significantly limited the scope of these patents by using the written description and enablement requirements, thus forcing applicants to specifically describe their invention by giving structural elements to the claimed antibody. The Federal Circuit is willing to invalidate

\footnotetext{
${ }^{59}$ See Figure 2 and Section III(C) supra.

${ }^{60}$ See Table 1(showing that the 1650 control group exhibits more than two fold more obviousness rejections) and Figure 4 (showing that 103 rejections comprise less than $10 \%$ of the rejections experienced by antibody patents are obviousness rejections, while most other inventions receive seven times more obviousness rejections).

${ }^{61}$ S. Sean Tu, Patenting Fast and Slow: Examiner and Applicant Use of Prior Art, 38 Cardozo Arts and Entertainment Law Journal 101 (2020).

${ }^{62} \mathrm{~S}$. Sean $\mathrm{Tu}$, is the sole author of Section IV. Christopher Holman does not concur with the recommendations proposed in this section.
} 
patents and reverse billion-dollar judgements based on the written description and enablement requirements. ${ }^{63}$ The courts and the USPTO administration, however, have been slow to implement change in response to the changes to antibody technology. In contrast, patent examiners have been actively rejecting patents based on these theories for over a decade.

\section{A. Allow Science to Guide the Law}

Interestingly, patent examiners applied these enhanced patentability rules for written description and enablement independent of court cases or even in the face of the USPTO written description rules that would otherwise allow broad patent claims. Specifically, patent examiners were forcing applicants to disclose structural features (and not just describing the antigen) before many changes in the caselaw and even after the 2008 USPTO written description guidelines that specifically stated that antibody claims based on antigen structure alone could satisfy the written description requirement.

This phenomenon is most likely due to the fact that most patent examiners in this technology center are highly educated scientists ${ }^{64}$ and although they do apply the legal rules for patentability, they do so through the lens of a scientist. Patent examiners, therefore, are the most in tune with changes in technology.

Most patent examiners in this technology center, however, do not have a law degree. ${ }^{65}$ Patent examiners are also unlikely to be in

${ }^{63}$ See Centocor Ortho Biotech, Inc. v. Abbott Lab'ys, 636 F.3d 1341 (Fed. Cir. 2011) (where the Federal Circuit overturned a $\$ 1.67$ billion dollar verdict and invalidated a set of patents based on the lack of written description); Juno Therapeutics Inc. v. Kite Pharma, Inc., No. 20-1758 (Fed. Cir. 2021)(where the Federal Circuit reversed a $\$ 1.2$ billion dollar verdict and invalidated a patent based on lack of written description); Amgen Inc. v. Sanofi, 987 F.3d 1080 (Fed. Circ. 2021)(where the Federal Circuit affirmed invalidation of a set of patents based on the enablement requirements);

${ }^{64}$ S. Sean Tu, Paul Gugliuzza, and Amy Semset, Overqualified and Underrepresented: Gender Inequality in the Pharmaceutical Patent Field (2021, in manuscript)(Table 2, showing that over $50 \%$ of examiners have a Ph.D.)

${ }^{65}$ S. Sean Tu, Paul Gugliuzza, and Amy Semset, Overqualified and Underrepresented: Gender Inequality in the Pharmaceutical Patent Field (2021, in manuscript)(Table 2, showing that the only about $15 \%$ of patent examiners in TC1600 have a J.D.) 
tune with the most current changes to patent law jurisprudence. Accordingly, it is somewhat unsurprising that patent examiners have been applying a stricter written description and enablement standard than courts for over a decade. What is surprising is that they have largely ignored the USPTO's own 2008 written description guidelines that specifically allow broad antibody claims based solely on antigen structure. ${ }^{66}$ In the early days of antibody technology, these broad antigen defined antibody claims were allowable. After Lilly, it looked like antibody patents would be narrowed much like many other biotechnology inventions. ${ }^{67}$ However, the courts and the PTO carved out an exception for antibodies, which allowed them broader scope. The courts, however, have now caught up with what patent examiners have been doing for a decade, that is using the written description requirements to narrow antibody claims.

Denying broad antibody claims while allowing narrower antibody claims has produced robust growth in the antibody field. Ultimately, patent examiners help innovators by denying claims that would subsequently be struck down in court. Rejecting these patents spares investors from spending resources based on these patents. Additionally, this creates more certainty, predictability and confidence for investors.

By allowing narrower claims patent law strikes a balance between granting exclusive rights to what the inventor disclosed to the public while protecting against overly broad claims that may hinder innovation in the area. Additionally, unlike broad genus type patents, narrow patent rights incentivizes competitors to "design around" products to create additional novel therapeutic antibodies (even if they are directed towards the same antigen).

\section{B. Reverse Doctrine of Equivalents}

Patent law attempts to promote the progress of science by giving limited exclusive rights to inventors. This is a delicate

${ }^{66}$ Written Description Training Material, Revision 1, March 25, 2008. (Example 13, showing that a claim directed towards "An isolated antibody capable of binding to antigen X” can satisfy the written description requirements of 35 U.S.C. §112).

${ }^{67}$ Christopher M. Holman, Is Lilly Written Description a Paper Tiger: A comprehensive Assessment of the Impact of Eli Lilly and Its Progeny in the Courts and PTO, 17 Alb. L.J. Sci. \& Tech. 1 (2007). 
balance for the biologics field. On one hand it may be necessary to provide broader patent protection to motivate firms to take the risk to innovate in this technology, which requires high up front costs. ${ }^{68}$ On the other hand, giving too much protection can inhibit innovation by providing important follow on technology. Some commentators have argued that the pendulum has swung too far arguing that applicants are now inappropriately being denied genus claims. ${ }^{69}$

One solution to this delicate balance may lie in the rarely used Reverse Doctrine of Equivalents (reverse DOE). The reverse DOE allows improvers to capture the value associated with an invention that would literally infringe another's patent. Accordingly, the reverse DOE could offer a solution to reward improvers even though their improvements would literally infringe on a prior patent. ${ }^{70}$

The rarely used reverse DOE is a mechanism by which a court can find that an invention does not actually infringe on a patent even though it literally falls within the scope of the claims. ${ }^{71}$ The original example of reverse DOE occurred in 1869 when George Westinghouse invented a train brake that used compressed air from a central reservoir to stop the train. In 1887 George Boyden improved on this break by using compressed air from a central reservoir and a local reservoir in each brake cylinder. The Supreme

68 Olivier J. Wouters, Martin McKee, Jeroen Luyten, Estimated Research and Development Investment Needed to Bring a New Medicine to Market, 2009-2018, 323 JAMA 844 (2020) (showing that the median capitalized research and development investment to bring a new drug to market was estimated at $\$ 985.3$ million).

${ }^{69}$ Dmitry Karshtedt, Mark A. Lemley, and Sean B. Seymore, The Death of the Genus Claim, 35 Harvard Journal of Law and Technology (2022, forthcoming). Cf. Christopher M. Holman, Is the Chemical Genus Claim Really "Dead" at the Federal Circuit?: Part I, Biotechnology Law Report (in manuscript, 2022).

${ }^{70}$ Scripps Clinic \& Research Found. v. Genetech, Inc., 927 F.2d 1565, 1581 (Fed. Cir 1991) (suggesting that a device may escape liability under the reverse doctrine of equivalents because it is a radical improvement over the patented technology); Atlas Power Co. v. E.I. duPont de Nemours \& Co., 750 F.2d 1569 (Fed. Cir. 1984). See also Robert Merges, Intellectual Property Rights and Bargaining Breakdown: The Case of Blocking Patents, 62 Tenn. L. Rev. 75 (1994); Robert P. Merges, A Brief Note on Blocking Patents and Reverse Equivalents: Biotechnology as an Example, 73 J. Pat. \& Trademark Off. Soc'y 878 (1991).

${ }^{71}$ Ethyl Molded Prods. Co. v. Betts Package, Inc., 9 U.S.P.Q.2d 1001, 1026 (E.D.Ky. 1988) (stating that, "the reverse doctrine of equivalents, although frequently argued by infringers, has never been applied by the Federal Circuit."); see also Robert P. Merges, $A$ Brief Note on Blocking Patents and Reverse Equivalents: Biotechnology as an Example, 73 J. Pat. \& Trademark Off. Soc’y 878, 884 (1991) 
Court found that, the new invention "has so far changed the principle of the device that the claims of the patent, literally construed, have ceased to represent his actual invention."72 Similarly, the Court in Graver Tank stated that:

[W] here a device is so far changed in principle from a patented article that it performs the same or similar function in a substantially different way, but nevertheless falls within the literal words of the claim, the [reverse] doctrine of equivalents may be used to restrict the claim and defeat the patentee's action for infringement. ${ }^{73}$

As outlined by Merges, reverse DOE may be especially justified when the original patent contributes very little value compared to the improvement. ${ }^{74}$ When the improvement greatly increases the value of the original patent, then an inefficient holdup problem may become significant. The social costs of this holdup problem is also significant because the improvement must "sit on the shelf for the life of the original patent."75 Reverse DOE solves this problem by excusing the improver from infringement liability, thus preventing the patentee's holdup right. ${ }^{76}$

Reverse DOE may be a suitable response to the current situation where courts and the PTO only allow very narrow antibody claims. In calculating the balance between broad and narrow rights, we could default to allowing broad patents and then use reverse DOE to excuse liability for those follow on inventions that greatly increase the value of the original patent.

We may want to create a system where we initially give broad protection for novel inventions based on antibody technology then use the reverse DOE to exclude follow-on technology that greatly

\footnotetext{
72 Westinghouse v. Boyden Power-Break Co., 170 U.S. 537, 562 (1898).

${ }^{73}$ Graver Tank \& Mgf. Co. v. Linde Air Prods. Co., 399 U.S. 605, 608-09 (1950).

74 Robert P. Merges, A Brief Note on Blocking Patents and Reverse Equivalents: Biotechnology as an Example, 73 J. Pat. \& Trademark Off. Soc'y 878, 885 (1991).

75 Robert P. Merges, A Brief Note on Blocking Patents and Reverse Equivalents: Biotechnology as an Example, 73 J. Pat. \& Trademark Off. Soc'y 878, 886 (1991).

${ }^{76}$ Robert P. Merges, A Brief Note on Blocking Patents and Reverse Equivalents: Biotechnology as an Example, 73 J. Pat. \& Trademark Off. Soc'y 878, 886 (1991).
} 
differs from the patented invention. Specifically, courts might use the reverse DOE in a case where a humanized or chimeric antibody that recognizes a different epitope or has significantly different functional characteristics from the patented antibody.

One possible application of this solution could be exemplified by the AbbVie case. ${ }^{77}$ The AbbVie court held two AbbVie patents invalid because they lacked adequate written description. These patents were directed to fully human antibodies that bind to and neutralize the activity of human interleukin 12 (IL-12). AbbVie obtained a broad patent directed to fully human anti-IL-12 antibodies. ${ }^{78}$ Although the AbbVie patents broadly claimed full human IL-12 antibodies, all of the disclosed AbbVie antibodies had: (1) VH3 heavy chains, (2) lambda light chains, (3) at least 90\% similarity with Joe-9 in variable regions and (4) more than $99.5 \%$ similarity in variable regions.

Centocor produced Stelara (ustekinumab) which was a fully human IL-12 antibody that neutralized the activity of IL-12. Stelara literally infringed the AbbVie patent. However, Stelara was structurally distinct from Joe and Joe-derived antibodies. Table 4 outlines these key differences.

Table 4

\begin{tabular}{|l|l|l|l|}
\hline & Stelara & J695 & Joe-9 \\
\hline Sequence Similarity & $50 \%$ & $90 \%$ & $90 \%$ \\
\hline CDR Length & Different & Identical & Identical \\
\hline Epitope Binding & Side & Bottom & Bottom \\
Site & Binder & Binder & Binder \\
\hline$V_{H}$ Family & $V_{H} 5$ & $V_{H} 3$ & $V_{H} 3$ \\
\hline Light Chain Type & Kappa & Lambda & Lambda \\
\hline
\end{tabular}

Instead of invalidating the AbbVie patents based on lack of written description, a court could have held the patents valid, but

${ }^{77}$ Abbvie Deutschland GMBH \& Co, v. Janssen Biotech, Inc., 759 F.3d 1285 (Fed. Cir. 2014).

${ }^{78}$ U.S. Pat. No. 6,914,128 and 7,504,485 (exemplary claim 29 of the ' 128 patent reads, "A neutralizing isolated human antibody, or antigen-binding portion thereof that binds to human IL-12 and dissociates from human IL-12 with a $\mathrm{K}_{\text {off }}$ rate constant of $1 \times 10^{-2} \mathrm{~s}^{-1}$ or less, as determined by surface plasmon resonance.") 
excused Centocor from liability under the reverse DOE. Excusing liability under the reverse DOE in this case is rational because the Stelara antibody improvements changed the principle of the device in a way that no longer represented what AbbVie disclosed in the specification of their patents.

Allowing broad claims while carving out exceptions to those broad claims by using reverse DOE, however, is not a magic bullet. Reverse DOE is an ex post solution applied by courts only after heavy investment in the technology by competitors. Thus, reverse DOE does not address the incentives issue because competitors would not know ex ante if their antibody is "too similar" to the patented antibody. Accordingly, a rational competitor might simply avoid the risk of infringing a broad patent by never investing in research on new antibodies in the first place.

Additionally, if reverse DOE is applied too narrowly, then it would act identically to the current written description and enablement framework. Specifically, if reverse DOE is interpreted to only grant a scope exactly commensurate with those working examples disclosed in the specification, then it is no better than using the current written description and enablement standards.

\section{Conclusions}

Courts, the PTO administration, and patent examiners have all dealt with antibody patents in slightly different ways. However, it seems that all three arms have now reached a consensus. Each group is now using 112(a) to deny broad claims based only on function and antigen structure. However, narrow claims with antibody structural elements are currently allowed.

This study shows that patent examiners over time have increasingly used 112(a) rejections to narrow claims. Antibody patents moved from broad functional claims to narrow structurally limited claims. Finally, an increase in the number of words per independent claim and the increased use of continuation practice combined with shorter prosecution durations all suggest that the scope of antibody patents has narrowed over time. 
2-Feb-22] Orange Book Patent Prosecution and Litigation

Appendix 1- Antibody Fundamentals

\section{A. General Definitions}

1. Antigen- the target molecule that the antibody binds to.

2. Epitope- the specific region of an antigen that the antibody binds to.

3. Paratope- The region of an antibody that is responsible for binding to the epitope.

4. Complementarity Determining Regions (CDRs)- six regions on the antibody that collectively come into contact with the antigen. There are three CDR loops per variable domain in antibodies (three on the light chain and three on the heavy chain). CDRs on the light chain are labeled CDR L1, CRD L2 and CDR L3. CDRs on the heavy chain are labeled CDR H1, CRD H2 and CDR H3.

5. Light Chain / Heavy Chain- Antibodies are comprised of two light chains and two heavy chains in a Y-structure shown in Figure $X$. Each $Y$ contains two identical copies of a heavy chain and two identical copies of a light chain which are different in their sequence and length. The top of the $\mathrm{Y}$ shape is defined by the CDR sequences which form the paratope, which binds tightly and specifically to an epitope on the antigen.

6. Variable region- the region defined byt eh CDRs and surrounding framework regions.

7. Constant region- the part of an antibody that is common to its particular class. The constant region is involved in triggering the immune response and determines the mechanism by which the antigen is destroyed.

8. Polyclonal Antibody- a diverse population of antibodies targeted to the same antigen.

9. Monoclonal Antibody- a single antibody directed to a target epitope.

10. Bispecific Antibody- an antibody that can bind two targets.

11. Chimeric Antibody- An antibody that has been engineered from more than one different species. Commonly, the variable region is defined by a non-human antibody which is then linked to the constant region of a human antibody. This is done to limit the human immune response to a mouse antibody. 
12. Humanized antibody- A subclass of chimeric antibody where most of the sequences are human in origin.

\section{B. Antibody Structure, Function and Method of Production}

Antibodies, also known as immunoglobulins, are natural products of the body that are secreted by B-cells as part of an immunological response to neutralize antigens such as bacteria and viruses. The structure of an antibody is shown in Figure 1. The antibody structure is a classic Y-shaped molecule composed of two heavy chains (connected by a linker) and two light chains (connected to the heavy chains). Each tip of the " $Y$ " contains a paratope which can bind only one epitope on an antigen. This allows the antibody to bind its antigen with precision. There are two main types of antibodies: polyclonal and monoclonal. Monoclonal antibodies are identical and have the same binding specificity and recognize the same epitope. In contrast polyclonal antibodies against an antigen are a mixture of molecules having different binding sites, different binding specificities and typically recognize different epitopes on the antigen.

Figure 1

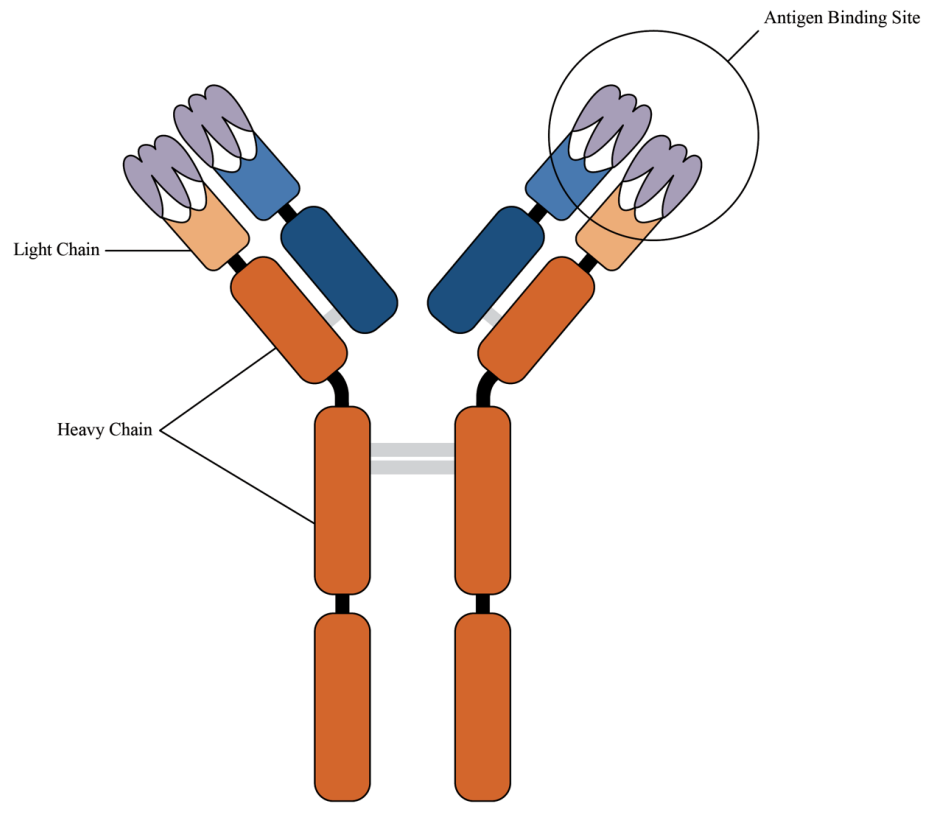


Polyclonal antibodies (pAbs) are a mixture of heterogenous antibodies which are usually produced. By different B cell clines in the body. Thus, pAbs recognize and bind to many different epitopes of a single antigen. Polyclonal antibodies are usually generated by injecting an animal with an antigen. After injection, the animal elicits a primary immune response, and then given a secondary injection (and sometimes a third injection) to boost the immune response. The serum ${ }^{79}$ can then be collected and polyclonal antibodies to the antigen can then be isolated using an immobilized antigen.

There are several benefits associated with pAbs. First, is the relative ease and cost of production of pAbs. pAbs are highly stable and can tolerate $\mathrm{pH}$ or buffer changes. $\mathrm{pAbs}$ bind more than one epitope and can help amplify the signal from a target protein even with low expression levels. Accordingly, pAbs are ideal for immunoprecipitation and chromatin immunoprecipitation. Finally, pAbs are less sensitive to antigen changes such as denaturation, polymorphisms and different glycosylation patterns. One major downside to pAbs, however, is the fact that there is batch to batch variability because each animal will mount a different immune response to the antigen injection. Polyclonal antibodies have been used as components of antivenom, antitoxin, and transplant antirejection drugs. Importantly pAbs are also used to detect disease in blood or tissue samples. For examples, pAbs have been used to detect for viruses, cancers, encephalitis, HIV and Lyme disease.

Monoclonal antibodies (mAbs) revolutionized antibody technology. In contrast to pAbs, mAbs are usually not produced in live animals. In 1975, Nobel laureates Kohler and Milstein produced the first mAbs. ${ }^{80}$ Monoclonal antibodies are generated using hybridoma technology, which is a product of splenocyte and myeloma cell fusions creating an immortalized B-cell-myeloma hybridoma. The hybridomas are able to grown continuously in culture while producing antibodies. These antibodies are then

\footnotetext{
${ }^{79}$ Serum consists of blood where the clotting proteins and red blood cells are removed.

${ }^{80}$ George Kohler and Cesar Milstein, Continuous cultures of fused cells secreting antibody of predefined specificity, 256 Nature 495 (1975). George Kohler and Cesar Milstein shared the 1984 Nobel prize in medicine for this breakthrough.
} 
screened for the desired mAbs. Importantly, monoclonal antibodies exhibit precise and reproducible binding properties. Monoclonal antibodies bind one specific epitope on an antigen.

Figure 2A describes the different binding specificities of mAbs compared to pAbs. Polyclonal antibodies have the ability to bind different epitopes (triangles and rectangles) on the same antigen. In contrast, mAbs can bind only one specific epitope (triangles) on an antigen. Figure $2 \mathrm{~B}$ shows that polyclonal antibodies bind to multiple epitopes on the same antigen, while monoclonal antibodies can bind to only one epitope.

Figure 2A

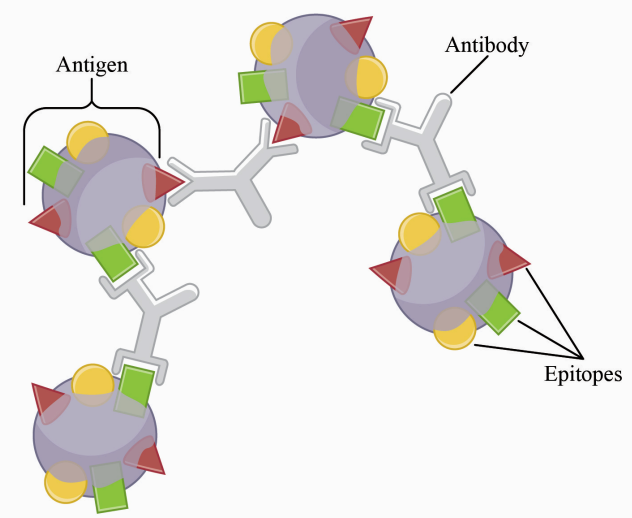

Polyclonal Antiserum

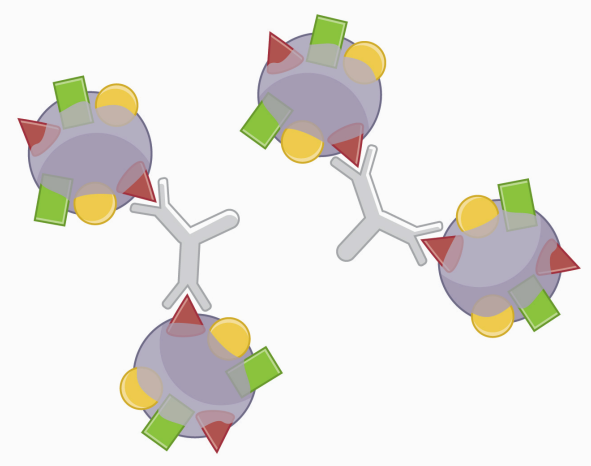

Monoclonal Antibodies

Figure 2B 
Polyclonal Antibody

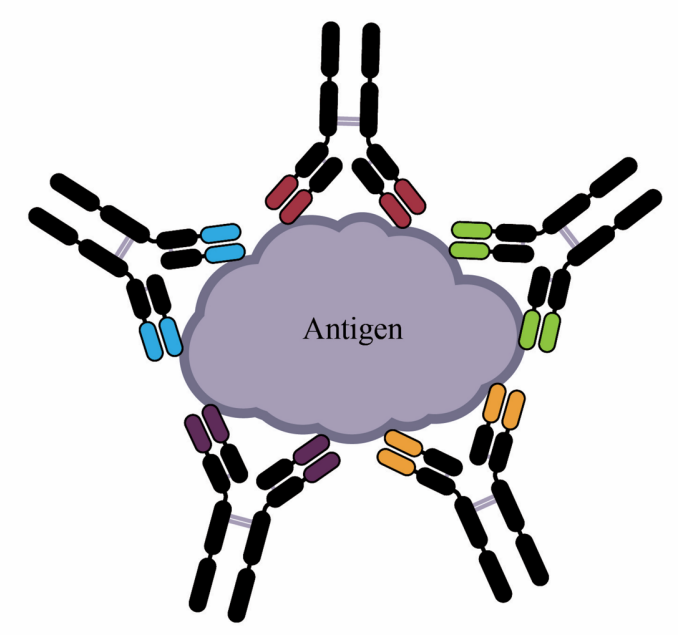

Monoclonal Antibody

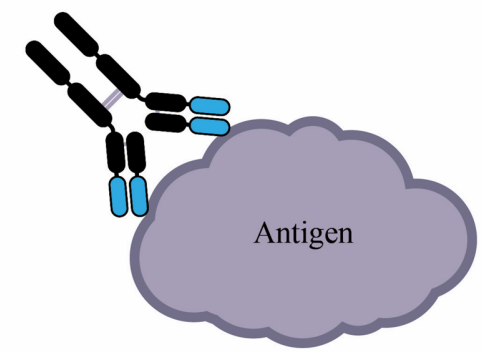

The benefits of using mAbs cannot be understated. First, $\mathrm{mAbs}$ are highly specific and recognize only one epitope of an antigen. Second, once an immortal hybridoma cell line is created, the firm has the ability to produce unlimited quantities of the $\mathrm{mAb}$. Because mAbs recognize only one epitope, the results of mAbs are highly consistent with minimal background noise and crossreactivity. However, the cost and time needed to generate monoclonal antibodies is considerably greater than polyclonal antibodies. Additionally, it takes a much longer amount of time and requires highly technical knowledge to create these hybridomas. Additionally, mAbs are vulnerable to changes in the epitope and even small changes in antigen conformation may lead to dramatically reduced binding capacity. Due to these consistent results, mAbs are much better suited to be used for therapeutic treatments. Accordingly, mAbs have been used to treat diseases such as rheumatoid arthritis ${ }^{81}$, asthma ${ }^{82}$, psoriasis $^{83}$ and many forms of cancer ${ }^{84}$.

${ }^{81}$ Adalimumab (Humira) from Abbvie is a fully human antibody against TNF used to treat rheumatoid arthritis.

${ }^{82}$ Dupilumab (Dupixent) from Regeneron Pharmaceuticals is a fully human antibody against IL4RA used to treat atopic dermatitis and asthma.

${ }^{83}$ Infliximab (Remicade) from Centocor is a chimeric antibody against TNF that is used to treat Chron's disease and plaque psoriasis.

${ }^{84}$ Atezolizumab (Tecentriq) from Genentech is a humanized antibody against PD-L1 that 
Monoclonal antibodies produced using mouse hybrdiomas are not ideal for use as human therapeutics. This is because humans injected with mouse mAbs will mount an immune response because the human body will recognize the mouse $\mathrm{mAb}$ as foreign and attempt to remove it from the body. This response is known as the Human Anti-Mouse Antibody (HAMA) response, and occurs when the human immune system recognizes the mouse antibody as foreign and attack it. A HAMA response can cause toxic shock or even death in a patient. Additionally, most mouse mAbs suffer from a short serum half-life in humans.

Accordingly, additional steps are required for mAbs that will be used for treatment of disease in humans. Monoclonal antibodies must be "humanized" for human clinical use. Figure 3 shows the humanized and chimeric versions compared to mouse antibodies. Chimeric and humanized antibodies reduce the likelihood of a HAMA response by minimizing the non-human portions of administered antibodies. Thus, because most regions of the chimeric and humanized antibodies are human, these antibodies do not elicit as much of an immune response from the patient. Furthermore, chimeric and humanized antibodies have the additional benefit of activating secondary human immune responses such as antibody dependent cellular cytotoxicity. Furthermore, these chimeric / humanized antibodies have a much longer serum half-life.

Chimeric antibodies are created by substituting the mouse constant region with a human constant region. Thus, the chimeric antibody consists mainly of a human constant region with only the variable regions of the antibody of mouse origin.

Humanized mAbs are created through genetically engineering the mouse B-cell so that the variable regions of the mouse light and heavy chain genes are ligated to human constant regions. This creates an antibody that most of the mouse sequence has been replaced with human Ig sequence. This process results in

is used to treat Urothelial carcinoma and metastatic non-small cell lung cancer; Bevacizumab (Avastin) from Genentech is a humanized antibody against vEGF used to treat metastatic colorectal cancer; Pembrolizumab (Keytruda) from Merck is a humanized antibody against PD-1 that is used to treat metastatic melanoma; Rituximab (Rituxan) from Genentech is a chimeric antibody against CD20 that is used to treat B-cell non-Hodgkin's lymphoma. 
2-Feb-22] Orange Book Patent Prosecution and Litigation

the production of a mAb that is mostly "human" with only the antigen binding site being of mouse origin. Because the $\mathrm{mAb}$ is mostly human in origin, the patient does not recognize the humanized $\mathrm{mAb}$ as foreign and does not generate large quantities of anti-mAb antibodies that would hinder the therapeutic $\mathrm{mAb}$ 's effectiveness.

One of the newest antibody technologies involve use of a phage display library to artificially construct soluble Fab fragments. These Fab fragments have the ability to penetrate tissues efficiently and do not need to be processed through the endoplasmic reticulum.

However, one major drawback to this approach is that a new phage library must be constructed for every antigen, which is a timeconsuming process. Additionally, Fabs are not full-length antibodies and lack the $\mathrm{C}$ region which is responsible for effector functions. Additionally, Fabs are produced in bacteria and therefore are not glycosylated, which leads to a much shorter half-life.

Finally, $\mathrm{mAbs}$ are being produced in plants for use in humans. These "plantibodies" are full length antibodies that are glycosylated and thus have a longer half-life in the patient's body. Plantibodies are generated by creating a transgenic plant that express human $\mathrm{mAbs}$ without harming their own metabolism. Accordingly, large quantities of human mAb can be created cheaply and the seeds produced by these plants can be easily stored.

Figure 3 

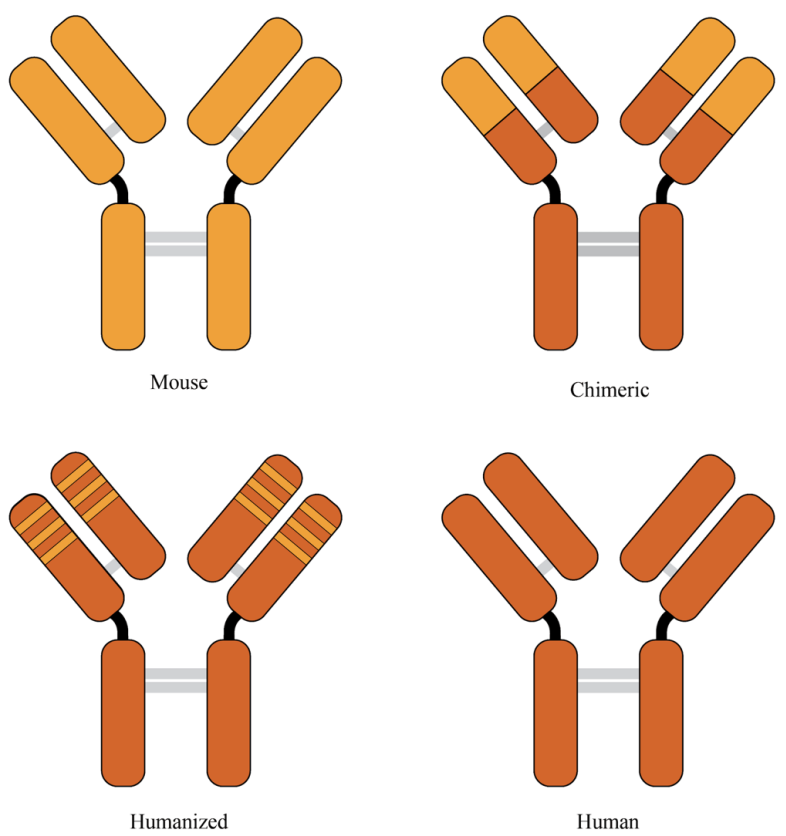